\title{
Signaling before the deadline: management earnings forecasts and performance-based vesting
}

\author{
July 23, 2020
}

\begin{abstract}
We study whether managers release more favorable management earnings forecasts (MEF) when approaching the end of the performance measurement period (PMP) and examine whether such disclosure behavior is out of signaling or strategic consideration. We find that MEFs convey more favorable but unbiased news as the end of the CEO's market-based PMP nears. Firms with lower past stock return and higher investor attention release the favorable and unbiased MEF to a greater extent than other firms. We find that investors react more positively to MEFs close to PMP than other MEFs with the same level of good news, suggesting higher credibility of the interested MEFs. Overall, our results are consistent with the signaling hypothesis that underperformed firms release more positive MEFs to inform the market about their potentials before the end of market-based PMP. Our paper documents an additional incentive coming from the compensation scheme for the firm's voluntary disclosure decision.
\end{abstract}

Keywords: Management earnings forecast; market-based performance metrics; executive compensation; optimal compensation contract 


\section{INTRODUCTION}

This paper investigates whether CEOs alter the information flow when approaching the end of a market-based performance measurement period (PMP) and whether such behavior is of a strategic or signaling consideration. Out of concern that the traditional time-vesting provisions of executives' equity-based awards do not give top management sufficient financial incentives, a growing number of firms have been urged to adopt performance-based vesting conditions for both the option and stock awards of their executives' pay scheme (Bettis, Bizjak, Coles, and Kalpathy 2010,2018$).{ }^{1}$ These performance conditions are increasingly popular in recent two decades: the percentage of firms adopting performance-based vesting increased from 45 percent in year 2006 to 86 percent in 2017 in our sample. ${ }^{2}$

Market-based metrics is one major type of the performance metrics used in the performance-based vesting provision with the purpose of aligning the CEO's compensation and investors' wealth. ${ }^{3}$ The percentage of firms that grant performance-based vesting restricted stock units (RSU) with market-based metrics ranges from 8.2 percent to 18.7 percent, and the pattern is on the upswing, with a peak in 2015 (Panel A of Table 2). However, on the other hand, too much stock price concerns may exert pressures on mangers to take myopic corporate decisions to maintain short-run stock performance at the expense of long-term value creation. This lapse in

\footnotetext{
${ }^{1}$ In firms adopting performance-based vesting provisions of equity grants, the criteria for number of units vested or accelerated are based on one or multiple types of performance metrics, rather than simply the passage of time. The performance metrics used for evaluation can be classified into three categories: 1) accounting-based metrics such as EPS, sales, or operating income, which reflect the firm's financial performance; 2) market-based metrics such as total shareholder return, stock price appreciation or static stock price target, which aim to more closely link the CEO's and investors' interests; and 3) other nonfinancial metrics such as market share, innovation, or customer satisfaction, which reflect the company's overall performance using nonfinancial measures (De Angelis and Grinstein 2015).

${ }^{2}$ Our statistics is comparable to Bettis et al. (2018)'s statistics, which shows that the usage of performance-vesting equity awards to top executives in large US companies has grown from 20 to 70 percent from 1998 to 2012 .

${ }^{3}$ For example, Apple Inc. argues in their DEF 14 proxy statement that "The Compensation Committee chose Relative TSR as a straightforward and objective metric to evaluate our performance against the performance of other companies and to align the interests of our named executive officers with the interests of our shareholders in creating long-term value."
} 
the research necessitates empirical investigation into the incentives and consequences of marketbased metrics in pay design. This paper fills in the gap in the literature by examining two particular questions: Do executives take actions (voluntary disclosure) to help themselves achieve market-based benchmarks? Do such actions hurt or benefit the operating performance of the firm and the welfare of shareholders?

We focus on voluntary management earnings forecasts (MEFs) which affect stock prices but do not directly affect actual earnings. This property of MEFs allows us to distinguish managers' incentives induced by accounting-based performance targets and that stemming from market-based performance targets. We first examine whether CEOs issue more favorable MEFs when approaching the end of a market-based performance measurement period (PMP). Then we analyze whether sum positive disclosure is strategic for self-serving interest of the mangers or is used to signaling managers' private information about the better future performance of the firm. ${ }^{4}$ Ex ante, it is unclear whether strategic behavior should exist. On the one hand, market-based performance criteria provide incentives to underperforming CEOs to boost stock prices when approaching the end of the measurement period. Favorable earnings forecasts will update analysts and investors' expectation about a firm's future performance and therefore lead to positive market reactions (Baginski and Hassell 1990; Pownall, Wasley, and Waymire 1993). We label this hypothesis "strategic hypothesis".

On the other hand, managers may not use the positive MEFs to opportunistically boost stock prices in the short-run for at least three reasons. First, such disclosures are very costly due to litigation concerns (Francis, Philbrick, and Schipper 1994; Rogers, Buskirk, and Zechman 2011) or reputation concerns (Beyer and Dye 2012; Cassell, Huang, and Sanchez 2013). Second,

\footnotetext{
${ }^{4}$ We focus on CEOs' incentive scheme because it is usually the CEO's decision to issue earnings forecasts. In an untabulated table, we use CFOs' restricted stocks grants but find no significant results.
} 
investors can figure out when the PMP ends based on public information, leaving limited room for strategic information releasing. ${ }^{56}$ Third, superior performance for the first period will lead to an even higher benchmark in the next period, which will be harder for the executive to achieve, given the repeating nature of awards granting. Therefore, we posit that the positive MEFs are used to convey managers' favorable private information, i.e., signaling undervaluation (Trueman 1986). That is, as the end of market-based PMP nears, the undervalued firms release positive MEFs which help the investors to form a more favorable and more accurate expectation about the firms' stock price, benefiting both managers and shareholders. We label this hypothesis "signaling hypothesis".

Using 26,828 observations for publicly traded U.S. firms spanning from 2006 to 2017, we analyze the tone of the MEFs (i.e., MEFs minus analyst consensus, scaled by lagged stock price) when approaching the end of PMP for CEOs. In this paper, we focus on one major type of equity incentive pay, the restricted stock unit (RSU), because 76 percent of the market-based metrics concentrate on the RSU award type and only 7.5 percent of the market-based metrics are attributed to the option grants. ${ }^{7}$ Therefore, we believe managers have a greater incentive to alter

\footnotetext{
${ }^{5}$ The timing of PMP ending date is available by adding the length of the period over which the CEO's performance is evaluated to when the equity awards are granted (the grant date). For example, in Appendix B, Cypress Semiconductor Corporation's CEO was granted a multi-year restricted stock award in fiscal year 2015. The award vests over a one-, two- or three-year period, and therefore, evaluation occurs over a similar period.

${ }^{6}$ However, market may still be fooled if the investors fail to keep track of the date and reverse the good news content of the CEO's disclosure because the PMP end date does not have a schedule as earnings announcement dates do, especially for firms with more retail investors. In such a case, CEOs still have considerable discretion over the flow of information around the PMP.

${ }^{7}$ The rest generally belongs to the cash awards, which are not equity incentives and not in the scope of this study. The price metric for option grants is usually an additional requirement accompanied with time-based vesting of option, which makes managers tend to still consider the option grants as time-based vesting ( 88 percent of the option grants are time-based vesting).
} 
information flow around vesting of RSU than other award types. ${ }^{8}$ We identify the associated performance metrics as well as the end date of PMP for each RSU grant. ${ }^{9}$

We find that the MEFs that the CEOs issues during the 180-day event window prior to the PMP end date of market-based metrics convey more good news relative to the prevailing analyst forecast consensus than do the MEFs the CEOs issue outside of the 180-day event window. The result is obtained after controlling for other factors that have been identified to influence MEFs tones. This result is also robust to inclusion of additional controls, a narrowed, 90-day eventwindow, and controlling for other corporate events that may impact management earnings forecast issuance. In comparison, for grants tied to non-market-based performance metrics, there is no significant difference in the tone for MEFs issued in or out of the 180-day window prior to the grant's PMP end date.

To distinguish the "strategic hypothesis" and "signaling hypothesis", we analyze the bias of MEFs (i.e., the value of MEFs minus the actual earnings, scaled by lagged stock price). The strategic hypothesis predicts that future actual earnings should be lower than forecasted valued while the signaling hypothesis predicts there is no difference between actual and forecasted earnings. Consistent with the signaling hypothesis, we find that there is no significant difference in the biases for MEFs issued in or out of the 180-day event window. This result suggests that the firms issuing good news forecasts in the pre-event window eventually manage to meet them. In untabulated results, we find positive earnings forecasts in the pre-event window do not lead to

\footnotetext{
${ }^{8}$ Although a small amount of the option grants is contingent on stock price, we didn't find the existence of favorable management forecasts for option grants.

${ }^{9}$ Several grants that have different performance metrics may have the same performance evaluation end. If each group of PMP has at least one grant with a market-based metric, we flag the vesting date as the stock price evaluation date because as long as one metric at the end date of PMP is associated with price, the CEO will have incentive to communicate with the market about his potential superior performance before the PMP end date.
} 
significantly higher abnormal accruals in the quarter of the actual earnings announcements, suggesting no evidence on firms managing the earnings up to meet their original forecasts.

For cross-sectional tests, we expect CEOs to have a greater signaling incentive when firms' past stock performance is relatively low, and when firms have higher levels of investor attention. First, we find that the good news disclosure induced by the approaching stock price evaluation date only exists for firms whose past-one-year stock performance is below the median, consistent with a stronger incentive to signal undervaluation for bad performers. Second, we hypothesize that firms choose to do voluntary disclosure for signaling purpose when their investor attention is high. Previous literature suggests that attentional constraints may be a source of market underreaction of accounting information and lack of monitoring from the market (Libby, Bloomfield, and Nelson 2002; Hirshleifer, Lim, and Teoh 2011; Kempf, Manconi, and Spalt 2017). Therefore, firms may have greater incentive to release forward-looking information for signaling purpose when they have higher level of attention from the investors. Using Kempf et al. (2017)'s firm-level shareholder “distraction” measures, we find evidence consistent with our hypothesis that firms with relatively high investor attention are likely to release positive MEFs before PMP to a greater extent than their counterparts.

Regarding the ex-post effect, our results show that the stock price response to forecast surprises is stronger for MEFs issued prior to a PMP end date than it is for MEFs outside of the event window. This result suggests stock price evaluation date induced good news MEF is more credible than other MEFs. We find there is no significant difference in the reversal over one month after the MEF issuance date for MEFs made in different periods. In Figure 2, we plot the monthly cumulative abnormal return for two subsamples, firms that issue positive MEFs in the 180-day pre-event window before the stock price evaluation date and firms that do not issue 
positive MEFs in the 180-day pre-event window, from month -6 to month +3 relative to the stock price evaluation date month (month 0 ). Compared to the relatively flat or even moderately declining return pattern of firms that do not issue positive MEFs before the stock price evaluation date, the return pattern for firms that do shows an increase in the stock performance before month 0 . The return patterns after the evaluation period end month for the two samples do not appear to be significantly different. This figure visually shows how positive management earnings forecasts in the event window could lead to a rise in stock price.

Next, by looking at the consequence, we find a positive effect of the frequency of favorable MEFs issued in the 180-day window prior to the PMP and the number of vested shares (i.e., shares obtained after reaching performance targets). More positive MEFs in the event window also positively predict accounting performance, measured as industry adjusted return on asset. These results suggest that both the $\mathrm{CEO}$ and the firm benefit from the performance pressure from the market-based PMP.

We then conduct a series of additional analyses, including a placebo test for firms with CEO turnover before all the evaluation periods end and a test including various kinds of corporate events that have previously identified to be related to MEF tones. Our PMP indicator surpasses most indicators based on other events except for insider purchases. Lastly, we conduct three robustness tests with 1) additional controls of leverage, accruals, and option delta 2) examine the propensity of issuing positive earnings forecasts by using an indicator variable as dependent variable 3) a narrowed event window of 90 days. All the tests confirm our results.

Overall, our paper's contributions are threefold: first, we bring the performance measurement period end date to people's attention and link management disclosure behavior with the benchmarks used to evaluate the CEO's performance at that date. We add to the broader 
literature on demands for managers' voluntary disclosure such as to reduce information asymmetry and the cost of capital (Coller and Yohn 1997, Verrecchia 2001, Brown, Hillegeist, and Lo 2004), to signal their ability (Trueman 1986), or to reduce litigation costs (Skinner 1994). In these cases, managers' and investors' disclosure preferences are aligned. In other cases when managers' and investors' disclosure preferences are not aligned, managers need to be motivated to disclose information to investors (Nagar, Nanda, and Wysocki 2003; Cheng and Lo 2006). Nagar et al. (2003) argue that stock price-based incentives in the form of stock-based compensation and share ownership mitigate this disclosure agency problem by documenting a positive relationship between CEO's stock-based compensation and firms' disclosure. In a similar vein, our paper extends this strand of literature by documenting that market-based metrics used in compensation schemes can potentially align the disclosure preferences between the agency and principal and so that work as another driving factor for timely disclosure of favorable news. That is, our study links the two sides of the literature in the following way: although the market-based PMP related positive disclosure is for managers' self-serving purpose to increase their own compensation, the high cost, high likelihood of being detected, and the potential higher standards for future performance associated with the release of positive forecasts make strategic disclosure unlikely and only firms that are truly confident about their future accounting performance will make such positive disclosure.

Second, our paper also relates to the optimal contracting literature. Previous literature suggests that optimal CEO compensation contracting uses both price- and nonprice-performance measures in combination and the preference for one over the other is determined by the nonprice measure's, relative to the price measure's, "signal to noise" ratio, economic environment, financial reporting concerns, and managerial power or costs of manipulation(Lambert and 
Larcker 1987; Baiman and Verrecchia 1995; Core, Guay, and Verrecchia 2003; Core and Heidi 2017; Beyer, Guttman, and Marinovic 2014; De Angelis and Grinstein 2015; Li and Wang 2016). A recent paper, Bennett, Bettis, Gopalan, and Milbourn (2017) documents a negative effect of using static accounting-based metrics in performance-based vesting equity awards. Our study enriches this research by uncovering a potential benefit of using the stock price as a performance metric, which is to motive managers to translate the accounting performance into stock returns and so that to align the disclosure preference between managers and investors.

Third, this study also provides implications to standard setters on a revisit of the effect of accounting standards such as FASB ASC Section 718 which may encourage(discourage) firms to use accounting (stock price) as performance metrics (Bettis, Bizjak, Coles, and Kalpathy 2018). In addition, benefiting from the transparent disclosure after 2006's SEC new disclosure requirement, our paper is the first to document positive management forecasts around the PMP end (Figure 1). The evaluation date is pre-determined so that suffers from no endogeneity problems. The CEO has a natural motivation to boost the stock price in the run-up to the marketbased performance period end. Both the above characteristics of the evaluation period end offer the research benefits of investigating incentives for the CEO's disclosure behavior.

The remainder of the article is organized as follows: Section 3 discusses research design and data. Section 4 presents the main empirical results of our hypotheses on how CEOs alter the information flow for the market-based performance evaluation and some supplementary tests. Section 5 concludes.

\section{LITERATURE REVIEW}

\section{Managerial incentives and management voluntary disclosure}


Although our study relates to the broad literature on the firm-level determinants of voluntary disclosure such as to reduce information asymmetry and the cost of capital (Coller and Yohn 1997, Verrecchia 2001, Brown et al. 2004), to signal their ability (Trueman 1986), or to reduce litigation costs (Skinner 1994) or proprietary costs (Verrecchia 1983), our paper is mostly related the literature on how certain monetary incentives of the CEOs could impact corporate's voluntary disclosure activity. Majority of the researches in this strand of literature suggest managers are self-interest serving and their disclosure behavior is subject to the private benefit which could potentially hurt the firm. For example, Kothari et al. (2009) document that managers tend to withhold bad news and such tendency increases with stock-based compensation. Edmans Fang, and Lewellen (2017) and Edmans, Goncalves-Pinto, Groen-Xu, and Wang (2018) suggest when the dollar change in the value of the CEO's vesting equity increases, the firm experiences a decline in the growth of research and development and capital expenditure, positive earnings guidance and analyst revisions and more positive discretionary news releases. Before SarbanesOxley, some firms backdated exercise dates to enhance the profitability of their option exercise (Cicero 2009). Cheng, Luo, and Yue (2013) provide evidence regarding insider trading and find that managers strategically choose forecast precision for self-serving purposes before insider sales or purchases. Brockman, Martin, and Puckett (2010) find a significant increase in the frequency and magnitude of good (bad) news announcements in the CEO option's pre-exercise period when CEOs implement exercise-and-sell (exercise-and-hold) strategies. A similar vein of the literature finds that the managers intentionally issue bad news or negative earnings guidance around grant dates to lower the strike price or performance targets in annual incentive plans. (Aboody and Kasznik 2000; Daines, McQueen, and Schonlau 2018; Martin, Seo, and Yang 
2017). Alternately, they backdate the option grant dates (Yermack 1997; Heron and Lie 2007) to increase the option value.

On the other hand, a few studies show managers' disclosure out of efficient contracting. Nagar et al. (2003) argue that managers with higher levels of equity-based compensation issue more frequent forecasts to avoid equity mispricing that could adversely affect their wealth.

Our paper is distinct from and extends the above literature in two ways. First, we directly link managers' disclosure behavior with the benchmarks used to evaluate CEO performance. We make a distinction between accounting-driven and stock price-driven incentives based on different types of performance metrics. Separating out these two metrics enables us to compare how the CEOs make different discretionary disclosure decisions based on whether their compensation scheme has a stock price metric. Edmans et al. (2017) link the CEO's stock price concern to earnings boosts and positive earnings. However, Edmans et al. (2017) do not directly provide evidence on whether CEOs who are not concerned with the stock price will still inform investors via positive earnings guidance. Our paper suggests that without stock price concerns, CEOs do not release positive MEFs to attract investors' attention before earnings announcements, probably because of litigation concerns (Rogers et al. 2011) or reputation concerns (Beyer and Dye 2012). This finding offers insight into managers' compensation scheme design.

Second, we focus on the PMP end, which is different from the grant date or the vesting date, as illustrated by the timeline in Figure 1. For performance-based vesting grants, the compensation committee determines the options' strike price, the performance benchmarks, and the corresponding number of shares of vesting at the target, threshold, or maximum level at the grant date (DATE 1). CEO performance is then evaluated during the PMP ending at DATE 2 to determine the number of shares the executive earns (our dates of interest). A grant's total PMP 
may be divided into several intervals (ratable) with corresponding ratable vesting dates. The grant's vesting date is DATE 3. If the executives sell their vested shares immediately upon vesting, the stock price at the vesting date determines the dollar amount of the shares sold. The evaluation date is pre-determined and suffers from no endogeneity problems, so it offers research benefits much like the vesting date. However, a CEO is only incentivized to hype the stock before the vesting date if they intend to sell the vested shares. In contrast, in the run-up to the market-based evaluation date, the $\mathrm{CEO}$ has a natural motivation to boost the stock price. Therefore, the PMP end offers even better research advantages to examine the relationship between managerial incentive and voluntary disclosure than the vesting date.

Our paper extends the efficient contracting line of literature arguing that when approaching their market-based PMP ends, CEOs who feel their company's stock price do not fully reflect the expected strong accounting performance will have incentive to disclose their private information about the promising future of the firm so that to avoid the equity underpricing.

\section{Optimal contracting on price vs. non-price performance measures}

Regarding the determinants of the choice of performance metrics, agency theory suggests that firms prefer measures with high signaling quality in reflecting executive efforts (e.g., Jensen and Meckling 1976; Holmstrom 1979; Murphy 1985). Previous literature suggests that in optimal CEO compensation contracting, both price- and nonprice-performance measures are used in combination. Moreover, the usage of nonprice- vs. price- performance metrics is determined by the nonprice measure relative to the price measure's "signal to noise" ratio, financial reporting concerns and managerial power or costs of manipulation (Core et al. 2003;

Core and Heidi 2017; Lambert et al. 1987), and economic environment (Baiman and Verrecchia 1995; Beyer et al. 2014). De Angelis and Grinstein (2015) find that consistent with the argument 
that firms tend to choose performance measures that are more informative about CEO actions, firms with complex activities and large growth opportunities tend to rely more heavily on market-based measures, while more mature firms tend to be more closely linked to accountingbased measures. Focusing on multiyear accounting-based performance incentives, Li and Wang (2016) show that a firm's choice of incentive contracts also depends on its shareholders' horizon and the extent to which firm performance comoves with industry performance. Specifically, firms with more short-term shareholders are less likely to use multiyear accounting-based performance metrics and that firms use more relative performance evaluation when firm performance comoves more with industry performance.

Our data shows that the use of stock price-based metrics is usually of a longer-term and is evaluated relative to peers. However, the literature to date is silent on comparisons between the consequences of using price versus nonprice performance metrics. Bennett et al. (2017) document a negative effect of using static accounting-based metrics in performance-based vesting equity awards, our research highlights a potential benefit of using market-based performance metrics. It is our belief that compensation committees and consultants should consider structuring performance-pay contracts that are price-/nonprice-based to provide appropriate incentives that align with shareholders' interests and minimize accounting manipulation. ${ }^{10}$

\section{SAMPLE AND DATA}

Our paper uses two samples to test our hypotheses. The first is at the management earnings forecast level, with each MEF marked by whether it occurs during the 180-day event-window

\footnotetext{
${ }^{10}$ However, it's unclear and out of this study's scope whether CEOs take other strategic actions such as share repurchases to hype the stock price when using market-based hurdles.
} 
prior to the end of the PMP and whether the PMP end is associated with a price metric or a nonprice metric. To construct this sample, we first obtain from the Incentive Lab database of Institutional Shareholders Service (ISS) the PMP end and performance metric type for new CEO grants. ISS Incentive Lab extracts in-depth compensation data from firms' proxy statements on various aspects of all cash or equity awards (the target number of shares to be granted, the grant date, the PMP and the grants' vesting schedule) for named executive officers of S\&P 500 and a significant portion of S\&P 400 firms (backfill and forward fill data yields a total sample of more than 2,200 of the largest market capitalization firms).

Because the Securities and Exchange Commission (SEC) standardized the disclosure requirements for the grants of plan-based awards after 2006, we confine the sample period to between 2006 and 2017. We exclude RSU grants with time-based vesting provisions, ${ }^{11}$ leaving 1,013 firms that grant performance-based vesting provision RSU to their CEOs through the 2006 to 2017 period. To ensure the CEO still has incentives to boost the stock price at the evaluation date, we also exclude firms that experienced CEO turnover between the grant and the evaluation dates. ${ }^{12}$ We identify each performance-based vesting RSU grant's measurement period end date by adding the PMP to the grant date for each grant. For observations with missing grant dates, we use the most commonly used RSU grant date and the most commonly used grant date for the CEO, assuming that firms are more likely to grant the same type of award or same person on the same day.

One RSU may be associated with multiple performance metrics and performance can be evaluated over multiple periods. Therefore, after obtaining the evaluation dates for each CEO,

\footnotetext{
${ }^{11}$ RSUs with time-based vesting provisions account for 50.85 percent of our RSU sample.

${ }^{12} \mathrm{We}$ later use these excluded firms to do a placebo test; the results are insignificant, consistent with our expectation (Table 7).
} 
we flag dates based on whether a date is associated with at least one stock price metric. As long as one stock metric is associated with the identified evaluation date, it is treated as giving the $\mathrm{CEO}$ an incentive to communicate with the market and is flagged as a stock price evaluation date. For example, Cypress's CEO, T.J. Rodgers, is granted a performance-based vesting RSU on March $3^{\text {rd }}, 2015$, and is scheduled to be evaluated annually on three metrics (Total Shareholder Return, Synergy Milestone, and EPS; see Appendix B). Because the three evaluation dates, Jan. $3^{\text {rd }}$ of 2016, 2017 and 2018, are all associated with a market-based metric (TSR), they all need to be flagged as stock price evaluation date, even though not all the metrics associated with these dates are related to the stock price. Out of the contagion effect concerns, in cases where the evaluation date for a nonmarket-based metric is adjacent to a stock price evaluation date (the 30 days around it), we also flag the evaluation date as a stock price evaluation date because the MEFs issued during the event-window for these evaluation dates are also likely to convey good news. We constrain the sample so that firms have the same CEO at the grant and evaluation dates to ensure that the CEO still has the disclosure incentive. We obtain 9,001 firm-evaluation date pairs in total, and out of the 9,001 firm-evaluation date pairs, 1,449 of them are flagged as stock price evaluation dates.

After obtaining evaluation dates for each $\mathrm{CEO}$ of each firm, we merge the management earnings forecast data from the $\mathrm{I} / \mathrm{B} / \mathrm{E} / \mathrm{S}$ database with the firm-evaluation date pairs to identify whether the specific MEF falls within any of the 180-day event-window prior to the stock price evaluation date or non-stock price evaluation date. The merged data is then interacted with COMPUSTAT dataset for control variables, the CRSP database for the return files, and the $13 \mathrm{~F}$ database for institutional ownership to form a final sample of 26,828 MEFs issued by 580 firms 
through the period between 2006 and 2017. The sample selection procedure is presented in Table 1.

The second sample is at the CEO-year level. The target numbers of shares granted to each CEO if the target performance goals are met are aggregated to each fiscal year and the numbers of good news MEF issued during the event window for each evaluation date are averaged out for each fiscal year as well. We then merge this CEO-year data with Incentive Lab database to get the actual vested shares for each CEO during each fiscal year, which we use to proxy the number of shares that are earned. The final sample contains 2,286 CEO-year observations for 564 unique firms with 773 unique CEOs over the period from year 2006 to 2017.

Table 2 provides the summary statistics for the two samples (Panel B for the MEF sample, Panel C for the frequency of MEFs in the pre- and post-event window, and Panel D for the CEOyear sample) and the correlation matrix (Panel E and Panel F). In Panel B, the median for the difference between the management earnings forecast and analyst consensus $\left(M F \_G N\right)$ is negative, indicating there is more walk-down than walk-up earnings guidance. Price_Inwindow and Nonprice_Inwindow, respectively, are indicator variables equal to one for MEFs within the 180-day event-window prior to the stock price evaluation date or non-stock price evaluation date. We find that approximately 2.4 (2.9) percent of the 26,828 MEFs are in the 180-day eventwindow prior to stock price evaluation date (non-stock price evaluation date). The number for non-stock price evaluation dates is more than 5 times the number of stock price evaluation dates ${ }^{13}$, but the incidence of Nonprice_Inwindow is only 1.2 times that of Price_Inwindow. Therefore, the statistics show that the MEFs are more concentrated in the event windows for the stock price evaluation date, consistent with the conjecture that firms issue more earnings

\footnotetext{
${ }^{13}$ Out of the 9,001 firm-evaluation date pairs, 1,449 are stock price-based.
} 
guidance near the end of a price-metric-evaluation period than a nonprice-metric-evaluation period. Panel C confirms that the frequency of MEFs that fall into the 180-day pre-event window prior to market-based PMP end is significantly higher than the frequency of MEFs that fall in the post-event window. In comparison, the difference in frequency for the non-price based PMP is not that significant. In Panel D, Shrs_vest_scale is the number of the CEO's shares that vest during each fiscal year scaled by the firm's common outstanding shares (in millions) for the fiscal year of the vesting. Shrs_target_scale the total number of shares expected to be earned if performance targets are met for all performance-based vesting grants for each CEO in that fiscal year, scaled by the number of common shares outstanding (in millions) in the fiscal year of vesting. We find that the two variables are of a similar scale, while Shrs_target_scale has a higher mean albeit a lower median than Shrs_vest_scale. Log $(1+$ Inwindow_MF_GN_cnt $)$ is the $\log$ of 1 plus the total number of MEFs that are higher than the analyst forecasts that fall into the 180-day pre-event window before the PMP end date averaged by each firm-fiscal year of vesting. The mean of 1.082 for the $\log$ number corresponds to a raw number of 1.95 occurrences of positive MEF during the whole evaluation period.

\section{RESEARCH DESIGN AND EMPIRICAL RESULTS}

\section{Favorable MEFs toward the end of price-based versus nonprice-based PMPs}

We examine whether CEOs issue more favorable earnings forecasts during the 180-day event window prior to the stock-price PMP end by investigating whether the MEFs during this period contain good news. To test this hypothesis, we follow prior research and use the following regression model (Brockman, Khurana, and Martin, 2008): 


$$
\begin{aligned}
& M F_{-} N_{t}=\beta_{0}+\boldsymbol{\beta}_{1} \text { Price_Inwindow } t+\boldsymbol{\beta}_{2} \text { Nonprice_Inwindow } t_{t}+\beta_{3} \text { Size } t-1_{+}+\beta_{4} M t B_{t-1}+\beta_{5} \text { AbRet } t-1+ \\
& \beta_{6} \text { ROA }_{t-1}+\beta \text { EarnVol }_{t-1}+\beta_{8 \text { LosS }_{t-1}}+\beta_{9 \text { Horizon }_{t}}+\beta_{10} \text { Competition } t-1+\beta_{11} \text { InstitutionOwn }_{t-1} \\
& +\beta_{12} L n \_ \text {AnalystFollow } t-1+\text { YearFE }+ \text { QuarterFE }+ \text { FirmFE }+\varepsilon t,
\end{aligned}
$$

where $M F F_{-} G N_{t}$ is the dependent variable, defined as the management earnings forecast less the most recent prevailing consensus analyst forecast prior to the management forecast scaled by the stock price and multiplied by 100 to ease the interpretation of the economic magnitude. We use quantitative management annual EPS forecasts with point or range estimates with two ends. If the management EPS forecast is a range, we choose the midpoint (Rogers and Van Buskirk 2013; Bergman and Roychowdhury 2008). For the analyst consensus, we use the latest analyst consensus prior to the MEF issuance date; we obtain consensus forecast from the $\mathrm{I} / \mathrm{B} / \mathrm{E} / \mathrm{S}$ summary data.

Our main independent variable, Price_Inwindow, is an indicator variable that equals one if the MEF falls within the 180-day window before the PMP end for a grant that uses stock price as a performance metric (stock price evaluation date). In comparison, Nonprice_Inwindow is an indicator variable that equals one if the MEF falls within the 180-day window before the PMP end for a grant that does not use stock price to measure performance (non-stock price evaluation date). We expect a significant positive coefficient for Price_Inwindow $\left(\beta_{1}>0\right)$ and different effects for Price_Inwindow versus Nonprice_Inwindow on $M F_{-} G N\left(\beta_{1} \neq \beta_{2}\right)$.

We also include a comprehensive set of control variables. Firm size (Size) controls for the firm's overall information environment (Kasznik and Lev 1995). Market-to-book ratio (MtB) controls for growth opportunities and proprietary costs (Bamber and Cheon 1998). The abnormal return (AbRet) is used to control for the momentum effect and we include the return on assets 
(ROA) because the forecast type could be related to firm performance (Brockman et al. 2008). Following prior literature, we include the incidence of a loss (Loss) and earnings volatility (EarnVol) to control for the difficulty in predicting earnings because analysts' and managers' earnings forecasts are less precise for firms with negative or volatile earnings, which may affect managers' tendency to lowball earnings forecasts (Skinner 1994; Soffer, Thiagarajan and Walther 2000; Matsumoto 2002; Richardson, Teoh, and Wysocki 2004; Ke and Yu 2006). We control for the forecast horizon (Horizon), measured as the number of days between the management forecast date and the end of the fiscal period for which the forecast is issued, because the news content and specificity of management forecasts could be related to their timing (Matsumoto 2002; Rogers and Stocken 2005; Bergman and Roychowdhury 2008). ${ }^{14} \mathrm{We}$ control market competition (Competition) since firms facing higher product market competition might alter their voluntary disclosure practices (Li 2010). Analyst following (Ln_AnalystFollow) and institutional ownership (InstitutionOwn) are further controlled since firms often issue more precise forecasts in response to analysts' and institutional investors' demands (Baginski, Stephen, and Hassell 1997; Ajinkya, Bhojraj, and Sengupta 2005; Lennox and Park 2006).

We use an ordinary least square (OLS) regression model with standard errors clustered at the firm level. Firm and year fixed effects are included to control for firm-invariant and timeinvariant factors that may affect management earnings forecasts. In addition, we include MEF's fiscal quarter to address variance in management incentives to issue biased forecasts across the fiscal year (Matsumoto 2002). All continuous variables are winsorized at 1 and 99 percent levels.

\footnotetext{
${ }^{14}$ Previous literature also documents that litigation risk is one incentive for corporate disclosure (Philbrick and Schipper 1994). This literature uses an indicator variable for whether the firm is in certain industry to proxy for the litigation risk. Because we include firm fixed effects in our model specification, we do not need to control for litigation risk.
} 
Table 3 column (1) and (2) report the results for our hypothesis. Specifically, column (1) presents a basic regression without any control variables or fixed effects for a univariate comparison. Our main variable of interest, Price_Inwindow loads positively and is statistically significant at the 1 percent level. This evidence is consistent with our hypothesis that when the CEO's performance is evaluated based on stock price, MEFs issued in the 180-day event window before the evaluation period end contain more good news than do MEFs outside the event window and that they do so for the purposes of hyping the stock. From an economic perspective, the dependent variable $M F_{-} G N$ is 0.104 higher for MEFs issued within the 180-day event window than those issued outside it, which represents approximately 9.14 percent of the standard deviation of the $M F_{-} G N$ variable $(0.0914=0.104 / 1.138)$. In comparison, the coefficient for the indicator Nonprice_Inwindow appears to be insignificant, suggesting that the MEFs issued within or without the event window prior to the non-stock price evaluation date are not significantly different in the magnitude of their good news. This result still holds when adding the control variables identified as being related to the magnitude of $M F \_G N$, shown in column (2). We find that firm size (Size), firm growth $(M t B)$, and abnormal return (AbRet) in the preceding quarter are positively associated with MEFs with good news content, suggesting that larger firms and those with a better stock performance are more likely to issue a management earnings forecast that is more positive than the analyst consensus. Consistent with Brockman et al. (2008), we find that firms incurring losses (Loss) are less likely to issue favorable management earnings forecasts. Our results also show that good news content in MEF is negatively related to analyst following (Ln_AnalystFollow).

So far, we have shown that market PMP leads to an increase in good news content in management earnings forecasts. However, we have been silent on the nature of the change. Such 
an investigation can further shed light on whether market-based PMP provides benefits to the capital markets. To further examine if the positive earnings forecasts are also upward biased, we replace the dependent variable in equation (1) with MF_Bias, which is measured as the management earnings forecast less the actual earnings scaled by the stock price and multiplied by 100 . Column (3) and (4) show that when comparing to the actual earnings numbers, the management earnings forecasts in the event window are not significantly more biased than other management forecasts. That is, the firms issuing good news forecasts eventually manage to meet them to the similar extent comparing with other MEFs.

Overall, our results in Table 3 confirm that when CEOs approach the end of the marketbased-metric PMP, they have greater incentive to signal the market about their future ability of delivering strong accounting performance by issuing favorable but unbiased MEFs. In contrast, CEOs who are evaluated by only accounting-based or nonfinancial metrics have no incentive to disclose good news to signal the market as the PMP ends. ${ }^{15}$

\section{Cross-sectional analyses: Past stock appreciation and investor attention}

Stock prices do not always reflect the firm fundamentals. We argue when the firm's stock is more undervalued due to CEO's failure in translating the accounting performance into the stock return, the CEO will have greater incentive to issue more favorable earnings forecasts to inform the market so that to resolve the information asymmetry. In contrast, when a firm's analyst consensus is at the similar level of managers' belief and the stock performance is good enough to help the CEO reach the market-based performance benchmark before the PMP ends, the CEO would have less incentive to release their private information to signal the market.

\footnotetext{
${ }^{15}$ In Untabulated results, the precision of in-window and out-of-window management earnings forecasts are not significantly different.
} 
Therefore, we expect our main results to be weaker results for firms whose past return performance is higher. To test our hypothesis, we interact an indicator variable which equals to one if the cumulative monthly stock return for the 12 months is below the median (LowRet_12) before the disclosure date with Price_Inwindow. Column (1) in Table 4 presents the result.

Consistent with our hypothesis, the coefficient for the interaction (Price_Inwindow*LowRet_12) is significantly positive, suggesting that lower past stock performance incentivize the issuance of a positive management earnings forecast in the run-up to the evaluation period end. Regarding the magnitude of the moderating effect, after including the indicator variable LowRet_12 and the interaction term, we find that the coefficient of Price_Inwindow becomes insignificant, suggesting the MEFs issued in the pre-event window by firms with good stock performance (LowRet_12 $=0$ ) do not convey more favorable news than other MEFs. If the stock return is sufficiently high, the CEO will have no need to correct the stock price by issuing good news earnings guidance in the 180-day pre-event window. In unreported tables, we measure the stock returns in the past 18 or 24 months and find similar findings. In column (3) of Table 4 where MF_Bias is the dependent variable, the interaction term is not significant, suggesting that although the MEFs issued by worse stock performers before the end of the market-based PMP convey more good news, they are not significantly more optimistically biased. This result is consistent with the signaling hypothesis that the favorable MEFs are used to signal the better accounting performance of the firm rather than to opportunistically boosting stock price in the short-run.

To provide further evidence that the favorable MEFs before market-based PMP end is out of efficient contracting and so that used to reduce the information asymmetry between managers and the investors, we test if the firms with higher investor attention level will be more likely to 
issue such positive MEFs. Previous literature suggests that attentional constraints may be a source of market underreaction of accounting information and lack of monitoring from the market (Libby, Bloomfield, and Nelson 2002; Hirshleifer, Lim, and Teoh 2011; Kempf, Manconi, and Spalt 2017). Therefore, firms may have greater incentive to release forward-looking information for signaling purpose when they have higher level of attention from the investors so that to get stronger market reaction and reduce information asymmetry. We hypothesize that firms choose to do voluntary disclosure for signaling purpose when their investor attention is high.

We use the firm-quarter level shareholder "distraction" measure following Kempf et al. (2017). Their idea is that given investor $i$ in firm $f$ is more likely distracted if there is an attention-grabbing event (extreme returns) in another industry, and if that other industry is important in investor i's portfolio. They first compute an investor-level distraction score, and then aggregate across all investors in the firm. The distraction data is available from the authors' personal websites. The column (2) shows our result. The positive coefficient of the interaction term (Price_Inwindow*High_InvAttention) is consistent with our hypothesis that firms with relatively high investor attention are likely to release positive MEFs before PMP to a greater extent than their counterparts. The coefficient of Price_Inwindow becomes insignificant, which means the more favorable MEFs only exist for firms with high investor attention. Column (4) of Table 4 indicates that the MEFs issued by firms with high investor attention are not significantly more optimistically biased, which is consistent with signaling hypothesis.

\section{Market response to positive management earnings forecasts}


In this section, we seek to determine investors' reaction to the positive earnings forecasts issued in the run-up to the end of market-based PMP. To this end, we examine both the initial market reaction $(C A R(-1,1))$ to positive MEFs $\left(M F \_G N\right)$ and then in the subsequent reaction in the month that follows $(\operatorname{CAR}(2,30))$. The initial market reaction results are presented in Table 5, columns (1) and (2). Unsurprisingly, the coefficients for $M F_{-} G N$ are significantly positive, suggesting that the market reacts positively when MEFs are above the most recent analyst forecast consensus. Interestingly, the interaction term, Price_Inwindow*MF_GN, which captures whether MEFs that are within the 180-day event window prior the evaluation period end produces a more favorable market reaction than MEFs that fall outside that window but that have the same surprise magnitude (i.e. MEF minus analyst consensus). ${ }^{16}$ The implication of the positive coefficients for the interaction term is that the stock price evaluation date induced good news MEF is more credible than other MEFs, which is consistent with our "signaling hypothesis".

In columns (3) and (4), we show the results on whether the positive market reaction to positive MEFs later reverses. We find that the coefficients for Price_Inwindow*MF_GN on CAR (2, 30) are negative but insignificant, suggesting that the stock is underpriced before management's disclosure and the positive forecast the CEO issues restore it to a more accurate valuation. Figure 2 shows how the stock return patterns are different for firms that issue favorable MEFs in the 180-day event window before the stock price evaluation date versus those that do not. The abnormal returns are measured as the excess firm returns over the CRSP valueweighted return from month -6 to month +3 relative to the month of the stock price evaluation date (month 0 ). We can see that firms with favorable MEFs experience a positive trend before

\footnotetext{
${ }^{16}$ This result still holds after excluding the bundled management earnings forecasts to eliminate the confounding effect from earnings announcements;
} 
the end of the PMP (month 0) compared to the relatively flat return pattern for firms that do not issue favorable MEFs. This figure visually shows how positive management earnings forecasts could lead to increases in stock price and so that help managers achieve their market-based targets.

\section{Do CEOs benefit from issuing positive earnings forecasts? Do they perform better?}

In this section, we test whether managers acquire more shares and deliver better accounting performance as a result of compensation-oriented disclosure by regressing the vested shares or industry adjusted return on asset on the number of positive management forecasts using the following regression:

$$
\begin{aligned}
& \text { Shrs_vest_scale } t / A d j \_R O A=\quad \beta_{0}+\beta_{1} \log (1+\text { Inwindow_MF_GN_cnt })_{t}+\beta_{2} \text { Shrs_target_scale } t_{t}+\beta_{3} \\
& \text { Sizet }-1+\beta_{4} M_{t B} B_{t-1}+\beta_{5} R_{O A} \bar{A}_{t-1}+\bar{\beta}_{6} \text { Returnt } t-1+\beta_{7} \text { Volume }_{t-1}+\beta_{9} \text { Volatility }_{t} \\
& +\beta{ }_{8} \text { Losst-1 }+ \text { YearFE }+ \text { QuarterFE }+ \text { FirmFE }+\varepsilon t .
\end{aligned}
$$

We use the number of shares vested for each CEO for each fiscal year obtained from Incentive Lab scaled by the number of common shares outstanding in the fiscal year of vesting. The variable Shrs_vest_scale proxies for the number of shares earned by the CEO during each fiscal year as data on the number of shares the CEO actually earned is not available. The vested shares may include both time- and performance-based shares and is thus a rough proxy. However, if this proxy can still generate results as predicted, then the results should inform our hypothesis that favorable management forecasts can lead to a higher number of shares earned. We ensure that the fiscal year of the evaluation period end date is the same as the fiscal year in the stock vesting dataset. The sample is at the firm-fiscal year level. Inwindow_MF_GN_cnt stands for the number of positive MEFs that fall into the 180-day pre-event window before the PMP end date. 
Table 6 column (1) reports the results. We find a significantly positive coefficient on $\log$ $(1+$ Inwindow_MF_GN_cnt $)$, suggesting that issuing favorable MEFs in the 180-day pre-event window before the PMP end date contributes to CEOs receiving a higher number of vested shares. A one-standard-deviation increase in the $\log (1+$ Inwindow_MF_GN_cnt $)$ is associated with a $0.176 \times 10^{-6}\left(=0.205 \times 0.858 \times 10^{-6}\right)$ increase in vested shares scaled by outstanding shares in millions, which represents approximately 16.1 percent of the standard deviation (= $0.176 / 1.093)$ of Shrs_vest_scale. Our evidence suggests that management disclosures in the run-up to the PMP end help CEOs achieve market-based benchmarks and thereby increase their equity award payouts.

For the accounting performance, we regress industry adjusted ROA $\left(A d j \_R O A\right)$ of the evaluation year on $\log (1+$ Inwindow_MF_GN_cnt $)$ and find a positive relationship between the two variables (Table 6 column (2)). A one-standard-deviation increase in the $\log$ $(1+$ Inwindow_MF_GN_cnt $)$ is associated with a $0.0026(=0.0 .003 \times 0.858)$ increase in the industry adjusted ROA, which represents approximately 4.56 percent of the standard deviation (= $0.0026 / 0.057)$ of Shrs_vest_scale. We provide evidence the firms that are motivated to issue positive disclosure by market-based PMP also achieve stronger accounting performance in the end, which is consistent with the "signal hypothesis" that the positive forecasts are to signal better future performance rather than for strategic use of disclosure to boost stock price in the short-run.

\section{A Placebo test}

In this section, we conduct a placebo test based on the idea that when CEO turnover occurs before the full grant amount is earned, the former CEO's original grant evaluation dates should 
have no effect on the new CEO's earnings forecasts behavior. Specifically, we first identify cases where the CEO during the fiscal year of the predetermined evaluation dates is different from the CEO at the grant date of the RSU award. In such cases, we assume CEO turnover occurred between the previous evaluation date and the next one, if the firm has a different CEO for the latter. For our example firm Cypress (see Appendix B), the Multi-Year Performance Accelerated Restricted Stock Program granted in fiscal year 2015 was earned by CEO T.J. Rodgers over one-, two-, and three-year periods. If, in fiscal year 2017, the CEO is no longer T.J. Rodgers, then we assume a CEO turnover occurred in that year and flag the evaluation dates in fiscal years 2017 and 2018 as pseudo evaluation dates. We expect that the MEFs released toward the end of the 180 days before a pseudo evaluation date do not convey significantly favorable news for either price- or nonprice-based metrics. The results are shown in Table 7. The insignificant coefficients for both Price_Inwindow and Nonprice_Inwindow are consistent with our expectations.

\section{Controlling other corporate events linked to management earnings forecast behavior}

Previous literature documents that managers may issue a positive earnings forecast prior to an annual or board meeting to impress investors (Dimitrov and Jain 2011), before an equity offering to boost the stock price (Ge and Lennox 2011), before the CEO retires to receive higher compensation at no cost (Cassell et al. 2013). Alternately, managers may issue a negative (positive) earnings forecast before (after) a stock repurchase happens (closes) (Brockman et al. 2008). Previous literature also suggests that MEFs are more pessimistic prior to the grant date of performance-based vesting awards so management is given a lower performance benchmark (Aboody et al. 2000; Daines et al. 2018; Martin et al. 2017). Similarly, more positive MEFs are issued around the vesting date of stock or option grants when the vesting date is used as a proxy 
for managers' incentive to sell the stocks (Edmans et al. 2017, 2018). Gong, Li, and Yin (2019) find firms time their earnings release when their performance is evaluated based on peers. Cheng et al. $(2006,2013)$ suggest that managers alter information flow of firms around insider purchases.

To eliminate the possibility that our results are driven by these corporate events rather than the end of the evaluation period, we include dummies of whether the MEF also falls within a 30-day pre-event window for one of the eleven types of corporate events: an annual meeting, a board meeting, a follow-on equity issuance, a private placement issuance, a fixed income offering, CEO turnover, a stock buyback announcement, the closing of a stock buyback, grant date of RSU, vesting date of RSU, and trading date of insider purchase. The grant date and vesting date of RSU is obtained from Incentive Lab, the insider trading data is obtained from the Thomson Reuters, and the dates of other eight types of events are obtained from Capital IQ.

Our results in panel A of Table 8 show that the coefficient for our main variable of interest, Price_Inwindow, is still significantly positive after controlling for other corporate events. The results using our relatively small sample show that MEFs are more positive than the analyst consensus before the firm's has a follow-on equity issuance but more pessimistic before the insider purchase. These results are consistent with prior literature that managers issue positive news before equity offering and issue negative news before insider purchase. Our results also provide moderate support that firms issue positive earnings guidance after buyback transaction is closed. The magnitude of PMP induced MEF bias is still significant after controlling all these confounding events, which suggests a high importance of our event dates.

\section{Robustness check}




\section{Additional controls/alternative specifications}

Previous literature documents that firms' voluntary disclosure decisions are influenced by product market competition (Li, 2010), information demand from institutional investors (Ajinkya et al. 2005) and debt holders. We therefore controlled the industry's Herfindahl index (Competition), institutional ownership (InstitutionOwn) and the leverage ratio (Leverage). We additionally controlled firm's information environment proxied by analyst following (Ln_AnalystFollow) and earnings opacity measured by firm's total accruals (Accruals). We also include the option delta which gives the managers' incentive to manipulate earnings (OptionDelta). Our main results still hold after controlling all these factors (Table 9 Panel A column (1)).

Column (2) in Table 9 uses an alternative dependent variable $G N_{t}$, which equals one if the management earnings forecast is greater than the most recent prevailing consensus analyst forecast before the management forecast, and zero otherwise. The positive coefficient of Price_Inwindow suggests that management earnings forecasts fall into the pre-event window before the end of the market-based PMP is more likely to convey good news relative to the analyst forecasts.

\section{Narrowing the pre-event window to 90 days}

As there is no theoretical guidance about when managers start reporting positive news, we repeat our main regression by limiting our pre-event window to 90 days and treating the MEFs that fall within this event window as suspect. Narrowing the event window allows us to eliminate some of the potential influence of events other than the evaluation period end. Our results are tabulated in panel B of Table 9, columns (1) and (2). The coefficient for 
Price_Inwindow is still significantly positive, suggesting that MEFs issued in the 90-day preevent window are more positive than those issued outside it. In comparison, MEFs before the nonprice metrics evaluation date are not significantly different from the benchmarks, as the insignificant coefficient on Nonprice_Inwindow suggests.

\section{CONCLUSION}

This paper links voluntary corporate disclosure to managers' compensation contracts directly through market-based performance evaluation metrics. In the wake of increasing use of performance-based vesting provisions and stock price-based metrics for equity awards, we provide evidence that market-based metrics align the disclosure preference between managers and the shareholders by documenting the good news embedded in MEFs as the equity-aware evaluation period comes to a close. The good news forecasts reflect the CEOs private information about the firms' promising performance in the future and thereby eliminate the information asymmetry between the managers and the shareholders. The release of positive MEFs is mitigated by higher past stock performance and higher monitoring by institutional investors. By issuing positive management earnings forecasts, managers boost the stock price, a rise that is not fully unraveled in the following month, and which ultimately allows the manager to receive more shares. The managers motived by the favorable earnings forecasts turns out to deliver better accounting performance and meet their original walk-up forecasts. Our paper highlights the importance of the PMP end and brings it to investors and regulators' attention. The evaluation period and its end could induce various managerial strategic/efficient behaviors, depending on the differences between performance benchmarks. Our research also highlights a 
potential benefit of using market-based performance metrics in CEOs' compensation schemes which is to motivate translating accounting performance into stock returns. 


\section{REFERENCES}

Aboody, D., and R. Kasznik. 2000. Ceo Stock Option Awards and the Timing of Corporate Voluntary Disclosures. Journal of Accounting \& Economics 29(1): 73-100.

Ajinkya, B., S. Bhojraj, and P. Sengupta. 2005. The Association between Outside Directors, Institutional Investors and the Properties of Management Earnings Forecasts. Journal of Accounting Research 43(3): 343-376.

Baginski, S. P., and J. M. Hassell. 1997. Determinants of Management Forecast Precision. The Accounting Review 72(2): 303-312.

Baginski, S. P., and J. M. Hassell. 1990. The Market Interpretation of Management Earnings Forecasts as a Predictor of Subsequent Financial Analyst Forecast Revision. The Accounting Review 65(1): 175-190.

Baiman, S., and R. E. Verrecchia. 1995. Earnings and Price-Based Compensation Contracts in the Presence of Discretionary Trading and Incomplete Contracting. Journal of Accounting and Economics 20(1): 93-121.

Bamber, L. S., and Y. S. Cheon. 1998. Discretionary Management Earnings Forecast Disclosures: Antecedents and Outcomes Associated with Forecast Venue and Forecast Specificity Choices. Journal of Accounting Research 36(2): 167-190.

Bennett, B., J. C. Bettis, R. Gopalan, and T. Milbourn. 2017. Compensation Goals and Firm Performance. Journal of Financial Economics 124(2): 307-330.

Bergman, N. K., and S. Roychowdhury. 2008. Investor Sentiment and Corporate Disclosure. Journal of Accounting Research 46(5): 1057-1083.

Bettis, C., J. Bizjak, J. Coles, and S. Kalpathy. 2010. Stock and Option Grants with PerformanceBased Vesting Provisions. Review of Financial Studies 23(10): 3849-3888.

Bettis, J. C., J. Bizjak, J. L. Coles, and S. Kalpathy. 2018. Performance-Vesting Provisions in Executive Compensation. Journal of Accounting and Economics 66(1): 194-221.

Beyer, A., and R. A. Dye. 2012. Reputation Management and the Disclosure of Earnings Forecasts. Review of Accounting Studies 17(4): 877-912.

Beyer, A., I. Guttman, and I. Marinovic. 2014. Optimal Contracts with Performance Manipulation. Journal of Accounting Research 52(4): 817-847.

Brockman, P., I. Khurana, and X. Martin. 2008. Voluntary Disclosures around Share Repurchases 弥. Journal of Financial Economics 89(1): 175-191.

Brockman, P., X. Martin, and A. Puckett. 2010. Voluntary Disclosure and the Exercise of CEO 
Stock Options. Journal of Corporate Finance 16(1): 120-136.

Brown, S., S. A. Hillegeist, and K. Lo. 2004. Conference Calls and Information Asymmetry. Journal of Accounting and Economics 37(3): 343-366.

Cassell, C. A., S. X. Huang, and J. M. Sanchez. 2013. Forecasting without Consequence? Evidence on the Properties of Retiring Ceos' Forecasts of Future Earnings. The Accounting Review 88(6): 1909-1937.

Cheng, Q., and K. Lo. 2006. Insider Trading and Voluntary Disclosures. Journal of Accounting Research 44(5): 815-848.

Cheng, Q., T. Luo, and H. Yue. 2013. Managerial Incentives and Management Forecast Precision. The Accounting Review 88(5): 1575-1602.

Cicero, D. C. 2009. The Manipulation of Executive Stock Option Exercise Strategies: Information Timing and Backdating. The Journal of Finance 64(6): 2627-2663.

Coller, M., and T. Yohn. 1997. Management Forecasts and Information Asymmetry: An Examination of Bid-Ask Spreads. Journal of Accounting Research 35(2): 181-191.

Core, J. E., W. R. Guay, and R. E. Verrecchia. 2003. Price Versus Non-Price Performance Measures in Optimal Ceo Compensation Contracts. Accounting Review 78(4): 957-981.

Core, J. E., \& Heidi, P. (2017). Non-Price and Price Performance Vesting Provisions and Executive Incentives. Working paper.

Daines, R. M., G. R. McQueen, and R. J. Schonlau. 2018. Right on Schedule: Ceo Option Grants And opportunism. Journal of Financial and Quantitative Analysis 53(3): 1025-1058.

De Angelis, D., and Y. Grinstein. 2014. Performance Terms in Ceo Compensation Contracts*. Review of Finance 19(2): 619-651.

Dimitrov, V., and P. C. Jain. 2011. It's Showtime: Do Managers Report Better News before Annual Shareholder Meetings? Journal of Accounting Research 49(5): 1193-1221.

Edmans, A., V. W. Fang, and K. A. Lewellen. 2017. Equity Vesting and Investment. Review of Financial Studies 30(7): 2229-2271.

Edmans, A., L. Goncalves-Pinto, M. Groen-Xu, and Y. Wang. 2018. Strategic News Releases in Equity Vesting Months. The Review of Financial Studies 31(11): 4099-4141.

Francis, J., D. Philbrick, and K. Schipper. 1994. Shareholder Litigation and Corporate Disclosures. Journal of Accounting Research 32(2): 137-164.

Ge, R., and C. Lennox. 2011. Do Acquirers Disclose Good News or Withhold Bad News When 
They Finance Their Acquisitions Using Equity? Review of Accounting Studies 16(1): 183-217.

Gong, G., L. Y. Li, and H. Yin. 2019. Relative Performance Evaluation and the Timing of Earnings Release. Journal of Accounting and Economics 67(2-3): 358-386.

Heron, R. A., and E. Lie. 2007. Does Backdating Explain the Stock Price Pattern around Executive Stock Option Grants? Journal of Financial Economics 83(2): 271-295.

Hölmstrom, B. 1979. Moral Hazard and Observability. The Bell Journal of Economics 10(1): 7491.

Jensen, M. C., and W. H. Meckling. 1976. Theory of the Firm: Managerial Behavior, Agency Costs and Ownership Structure. Journal of Financial Economics 3(4): 305-360.

Kasznik, R., and B. Lev. 1995. To Warn or Not to Warn: Management Disclosures in the Face of an Earnings Surprise. Accounting review: 113-134.

Ke, B., and Y. Yu. 2006. The Effect of Issuing Biased Earnings Forecasts on Analysts' Access to Management and Survival. Journal of Accounting Research 44(5): 965-999.

Kim, J. B. 2016. Accounting Flexibility and Managers' Forecast Behavior Prior to Seasoned Equity Offerings. Review of Accounting Studies 21(4): 1361-1400.

Kothari, S. P., S. Shu, and P. D. Wysocki. 2009. Do Managers Withhold Bad News? Journal of Accounting Research 47(1): 241-276.

Lambert, R. A., and D. F. Larcker. 1987. An Analysis of the Use of Accounting and Market Measures of Performance in Executive Compensation Contracts. Journal of Accounting Research 25: 85-125.

Lang, M. H., and R. J. Lundholm. 1996. Corporate Disclosure Policy and Analyst Behavior. The Accounting Review 71(4): 467-492.

Lennox, C. S., and C. W. Park. 2006. The Informativeness of Earnings and Management's Issuance of Earnings Forecasts. Journal of Accounting and Economics 42(3): 439-458.

Li, X. 2010. The Impacts of Product Market Competition on the Quantity and Quality of Voluntary Disclosures. Review of Accounting Studies 15(3): 663-711.

Li, Z., and L. Wang. 2016. Executive Compensation Incentives Contingent on Long-Term Accounting Performance. The Review of Financial Studies 29(6): 1586-1633.

Martin, Seo, and Yang. 2017. Pessimistic Earnings Guidance before the Annual Incentive Plan. working paper. 
Matsumoto, D. A. 2002. Management's Incentives to Avoid Negative Earnings Surprises. The Accounting Review 77(3): 483-514.

Murphy, K. 1985. Corporate Performance and Managerial Remuneration: An Empirical Analysis. Journal of Accounting and Economics 7(1-3): 11-42.

Nagar, V., D. Nanda, and P. Wysocki. 2003. Discretionary Disclosure and Stock-Based Incentives. Journal of Accounting and Economics 34(1): 283-309.

Pownall, G., C. Wasley, and G. Waymire. 1993. The Stock Price Effects of Alternative Types of Management Earnings Forecasts. The Accounting Review 68(4): 896-912.

Richardson, S., S. H. Teoh, and P. D. Wysocki. 2004. The Walk-Down to Beatable Analyst Forecasts: The Role of Equity Issuance and Insider Trading Incentives. Contemporary Accounting Research 21(4): 885-924.

Rogers, J. L., and P. C. Stocken. 2005. Credibility of Management Forecasts. The Accounting Review 80(4): 1233-1260.

Rogers, J. L., and A. Van Buskirk. 2013. Bundled Forecasts in Empirical Accounting Research. Journal of Accounting and Economics 55(1): 43-65.

Rogers, J. L., A. Van Buskirk, and S. L. C. Zechman. 2011. Disclosure Tone and Shareholder Litigation. The Accounting Review 86(6): 2155-2183.

Skinner, D. J. 1994. Why Firms Voluntarily Disclose Bad News. Journal of Accounting Research 32(1): 38-60.

Soffer, Thiagrajan, and Walther. 2000. Earning Preannouncement Strategies. Review of Accounting Studies 5: 5-26.

Trueman, B. 1986. Why Do Managers Voluntarily Release Earnings Forecasts? Journal of Accounting and Economics 8(1): 53-71.

Verrecchia, R. E. 2001. Essays on Disclosure. Journal of Accounting and Economics 32(1): $97-$ 180.

Yermack, D. 1997. Good Timing: Ceo Stock Option Awards and Company News Announcements. The Journal of Finance 52(2): 449-476. 


\section{Figure 1 \\ Timeline for an equity grant with performance-based provisions}

\begin{tabular}{|c|c|c|c|}
\hline \multicolumn{2}{|r|}{ 180-day event window } & \multicolumn{2}{|c|}{ 180-day event window } \\
\hline 1 & 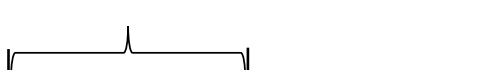 & 1 & $\lambda$ \\
\hline $\begin{array}{l}\text { Grant date } \\
\text { (DATE 1) }\end{array}$ & $\begin{array}{l}\text { performance measurement } \\
\text { period (PMP) } 1 \text { end date } \\
\text { (DATE 2) }\end{array}$ & $\begin{array}{c}\text { vesting date } 1 \\
\text { (DATE 3) }\end{array}$ & $\begin{array}{l}\text { performance measurement } \\
\text { period } 2 \text { end date } \\
\text { (DATE 2) }\end{array}$ \\
\hline
\end{tabular}

This figure shows the timeline for an performance-based equity award: on the grant date, the performance metrics and performance evaluation period and vesting schedule is determined; during the performance measurement period, the executive's performance is evaluated and the amount of the shares earned is determined; on the vesting date, the earned shared become sellable.

\section{Figure 2}

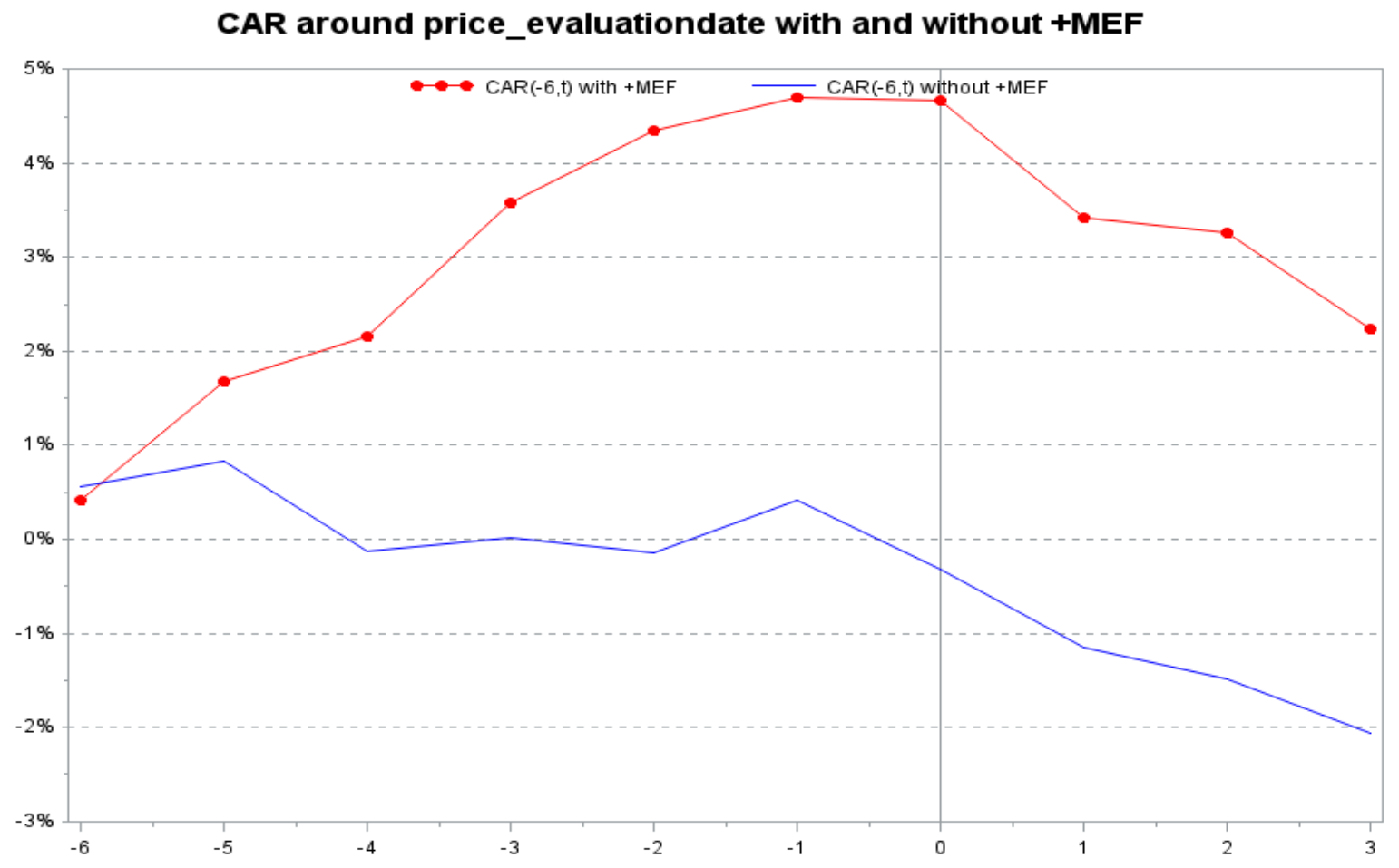

Figure 2 plots the monthly cumulative abnormal return for two subsamples, firms that issue positive MEFs in the 180-day pre-event window before the stock price evaluation date and firms that do not issue positive MEFs in the 180-day pre-event window, from month -6 to month +3 relative to the stock price evaluation date month (month 0 ). 


\section{Appendix A}

$M F \_G N_{t}$

MF_Biast

Price_Inwindowt

Nonprice_Inwindowt

Sizet-1

Market-to-Bookt-1

AbRett-1

$R O A_{t-1}$

EarnVolt-1

LosSt-1

Horizont

LowRet_12

High_Attention ${ }_{t-1}$

Shrs_vest_scalet

Shrs_target_scale $t$

$\log (1+\text { Inwindow_MF_GN_cnt })_{t-1}$
$M F \_G N_{t}$ is measured as management earnings forecast less the most recent prevailing consensus analyst forecast before the management forecast scaled by the stock price and multiplied by 100 .

MF Bias $t$ is measured as management earnings forecast less the actual earnings scaled by the stock price and multiplied by 100 .

$=1$ if the management earnings forecast is issued within the 180-day window before the end of PMP for a grant that uses stock price as one of its performance metrics, 0 otherwise.

$=1$ if the management earnings forecast is issued within the 180-day window before the end of PMP for a grant that does not use stock price as a performance metric, 0 otherwise.

Sizet-l is measured as the natural logarithm of firm $i$ 's market value of equity at the end of the fiscal quarter preceding the date of the management forecast.

Market-to-Bookt-l is measured as the market-to-book ratio at the end of the fiscal quarter preceding the date of the management forecast.

AbRett-l is defined as the cumulative abnormal returns, measured as the excess firm returns over the CRSP value-weighted returns during the three months ending 2 days before the issuance of the management forecast.

$R O A_{t-l}$ is calculated as income before extraordinary items in period $t-1$ divided by lagged total assets.

EarnVolt-I is measured as the standard deviation of quarterly earnings scaled by lagged total assets over the 12 quarters preceding the date of the management forecast.

Losst $-l$ is an indicator variable equal to one if the firm reported losses in period $t-1$ and zero otherwise.

Horizont $_{t}$ is measured as the difference between the date of the fiscal yearend and the date of the management forecast, divided by 365 .

LowRet_12t-1 $=1$ if the cumulated monthly stock return during the 12 months before the issuance of a management forecast is lower than the median, and 0 otherwise.

High_Attention $_{t-1}=1$ if the aggregated existing institutional shareholders' exposures to all concurrent extreme returns of other stock holding is below the median, and 0 otherwise.

Shrs_vest_scalet is measured as the number of shares vested for each CEO during each fiscal year scaled by the number of common shares outstanding (in millions) in the fiscal year of vesting.

Shrs_target_scalet is measured as the total number of shares expected to be earned if performance targets are met for all performance-based vesting grants for each CEO of that fiscal year scaled by the number of common shares outstanding (in millions) in the fiscal year of vesting.

Log $(1+\text { Inwindow_MF_GN_cnt })_{t-1}$ is measured as the log of 1 plus the total number of MEFs that are higher than the analyst forecasts that fall 
Returnt-I

Volume $_{\text {t-1 }}$ (in millions)

Volatility $_{t-1}$

Competition $_{t-1}$

InstitutionOwn $n_{t-1}$

Ln_AnalystFollow $t-1$

Leverage $t-1$

Accruals t-1 $^{-1}$

OptionDelta $_{t-1}$

Before_AnnualMeeting

Before_BoardMeeting

Before_FollowOnEquityt

Before_PrivatePlacement

Before_FixedIncomeOffering

Before_CEOTurnovert

Before_CFOTurnovert

Before_BuybackAnnoucet

After_BuybackClosing into the 180-day pre-event window before the PMP end date averaged by each firm-fiscal year of vesting.

Returnt-l $_{\text {is }}$ measured as the cumulative return in fiscal year $\mathrm{t}-1$.

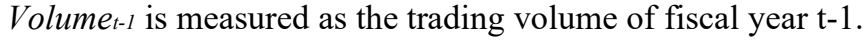

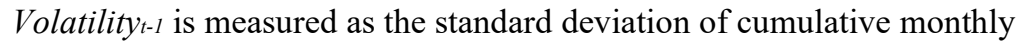
returns of fiscal year $\mathrm{t}-1$.

Competition $_{t-1}$ is measured as the Herfindahl index $\times(-1)$, where Herfindahl index is calculated as the sum of the squares of fractional market shares of firms within each two-digit SIC industry each quarter.

InstitutionOwn $n_{t-1}$ is measured as percentage of institutional ownership at the end of the fiscal preceding the date of the management forecast.

Ln_AnalystFollow $t-1$ is measured as $\ln (1+$ number of analyst forecasts $)$ in the month preceding the date of the management forecast.

Leverage $t_{-1}$ is measured as the total debt to total asset ratio at the end of the fiscal quarter preceding the date of the management forecast.

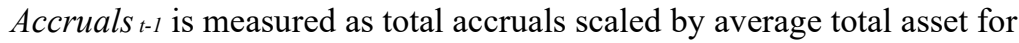
the fiscal quarter preceding the date of the management forecast.

OptionDelta $_{t-1}$ is the partial derivative of the option value with respect to stock price. Using the Black-Scholes model adjusted for dividend payouts (Black and Scholes, 1973) to value the options, option delta is given as $e^{-d T} \phi(\mathrm{Z})$.

$=1$ if the management earnings forecast falls within the 30-day window before the annual general meeting, 0 otherwise.

$=1$ if the management earnings forecast falls within the 30-day window before a board meeting, 0 otherwise.

$=1$ if the management earnings forecast falls within the 30-day window before an offering of follow-on equity, 0 otherwise.

$=1$ if the management earnings forecast falls within the 30-day window before a private placement, 0 otherwise.

$=1$ if the management earnings forecast falls within the 30-day window before a fixed income offering, 0 otherwise.

$=1$ if the management earnings forecast falls within the 30-day window before a CEO turnover, 0 otherwise.

$=1$ if the management earnings forecast falls within the 30-day window before a CFO turnover, 0 otherwise.

$=1$ if the management earnings forecast falls within the 30-day window before a buyback announcement, 0 otherwise.

$=1$ if the management earnings forecast falls within the 30-day window after a buyback transaction is closed, 0 otherwise. 
Before_GrantRSUt

Before_VestRSU

Before_InsiderBuyt
$=1$ if the management earnings forecast falls within the 30-day window before the grant date of restricted stock, 0 otherwise.

$=1$ if the management earnings forecast falls within the 30-day window before the vesting date of restricted stock, 0 otherwise.

$=1$ if the management earnings forecast falls within the 30-day window before the Insider purchase, 0 otherwise. 
Table 1: Sample selection

This table describes the sources of data and sample construction procedure.

\begin{tabular}{lcc}
\hline & $\begin{array}{c}\text { No. of unique } \\
\text { firms }\end{array}$ & $\begin{array}{c}\text { No. of unique } \\
\text { MEFs }\end{array}$ \\
\hline $\begin{array}{l}\text { No. of firms granted performance-based vesting RSU to their } \\
\text { CEOs from 2006 to 2017 (Data: Incentive Lab): }\end{array}$ & 1,013 \\
No. of firms out of the 1,013 firms that issues MEFs (Data: IBES & 702 & \\
Guidance): & & 34,545 \\
No. of MEFs issued for the 702 securities from 2006 to 2017: & \\
$\begin{array}{l}\text { Excluding: } \\
\text { No. of MEFs with missing data on control variables from COMPUSTAT/CRSP/13F: } \\
\quad\end{array}$ & 580 & $(7,717)$ \\
\end{tabular}


Table 2: Summary statistics

This table presents the summary statistics. Panel A reports the statistics for restricted stock unit (RSU) grants by year. $N_{-} p-v$ is the number of firms granting RSU with a performance-based vesting provision to CEOs. $N$ price is the number of firms that use price metric as one of the evaluation metrics for granted RSU with a performance-based vesting provision. Percent is $N \_$price scaled by $N \_p-v$. Panel B provides descriptive statistics for the key variables used in the management earnings forecast level analysis (Tables 3-5). Panel C reports the frequency of MEFs issued before and after the price vs. non-price PMP date. Panel D reports descriptive statistics for the key variables for CEO-year level analysis (Table 6). Panel E and Panel F report the Pearson correlation among variables for the two samples. * indicates significance levels at 5\%. All variables are defined in Appendix A.

Panel A: Annual distribution firms using performance-based vesting RSU with price-based metrics

\begin{tabular}{lcccccccccccc}
\hline & 2006 & 2007 & 2008 & 2009 & 2010 & 2011 & 2012 & 2013 & 2014 & 2015 & 2016 & 2017 \\
\hline$N_{-} p-v$ & 516 & 573 & 590 & 562 & 652 & 728 & 797 & 835 & 890 & 890 & 914 & 910 \\
$N_{\text {price }}$ & 48 & 56 & 60 & 51 & 60 & 73 & 107 & 120 & 152 & 166 & 75 & 85 \\
Percent & 0.093 & 0.098 & 0.102 & 0.091 & 0.092 & 0.100 & 0.134 & 0.144 & 0.171 & 0.187 & 0.082 & 0.093 \\
\hline
\end{tabular}

Panel B: Descriptive statistics for the management earnings forecast sample

\begin{tabular}{lcccccc}
\hline Variables & $\mathrm{N}$ & Mean & Std. Dev. & $\mathrm{Q} 1$ & Median & $\mathrm{Q3}$ \\
\hline MF_GN & 26828 & -0.109 & 1.138 & -0.122 & -0.017 & 0.054 \\
MF_Bias & 26828 & 0.076 & 2.774 & -0.241 & -0.072 & 0.016 \\
Price_Inwindow & 26828 & 0.024 & 0.153 & 0 & 0 & 0 \\
Nonprice_Inwindow & 26828 & 0.029 & 0.167 & 0 & 0 & 0 \\
Size & 26828 & 8.868 & 1.261 & 7.968 & 8.733 & 9.671 \\
MtB & 26828 & 3.894 & 4.626 & 1.706 & 2.725 & 4.237 \\
AbRet & 26828 & -0.006 & 0.155 & -0.094 & -0.004 & 0.082 \\
ROA & 26828 & 0.156 & 0.079 & 0.104 & 0.145 & 0.197 \\
EarnVol & 26828 & 0.013 & 0.016 & 0.004 & 0.007 & 0.014 \\
Loss & 26828 & 0.088 & 0.284 & 0 & 0 & 0 \\
Horizon & 26828 & 0.445 & 0.355 & 0.173 & 0.392 & 0.685 \\
Competition & 26828 & -0.069 & 0.071 & -0.072 & -0.041 & -0.031 \\
InstitutionOwn & 26828 & 0.800 & 0.211 & 0.721 & 0.838 & 0.926 \\
Ln_AnalystFollow & 26828 & 2.629 & 0.508 & 2.303 & 2.708 & 2.996 \\
Ret_12 & 26828 & 0.154 & 0.368 & -0.047 & 0.128 & 0.311 \\
Ln_age & 25540 & 4.039 & 0.109 & 3.970 & 4.043 & 4.111 \\
\hline
\end{tabular}

Panel C: frequency of MEFs in the 180-day pre- and post-event window

\begin{tabular}{|c|c|c|c|c|c|c|}
\hline $\begin{array}{l}\text { Price PMP } \\
\text { Nonprice PMP }\end{array}$ & 180-day & $\begin{array}{l}\text { e-windov } \\
1 \\
4 \\
\end{array}$ & & $180-\mathrm{d}$ & $\begin{array}{l}\text { post-wir } \\
83 \\
541 \\
\end{array}$ & \\
\hline \multicolumn{7}{|c|}{ Panel D: Descriptive statistics for the CEO-year sample } \\
\hline Variables & $\mathrm{N}$ & Mean & Std. Dev. & Q1 & Median & Q3 \\
\hline Shrs_vest_scale & 2286 & 0.729 & 1.054 & 0.152 & 0.373 & 0.864 \\
\hline Adj_ROA & 2286 & 0.005 & 0.057 & -0.020 & 0 & 0.024 \\
\hline Shrs_target_scale & 2286 & 1.049 & 3.579 & 0.136 & 0.302 & 0.695 \\
\hline $\log (1+$ Inwindow_MF_GN_cnt $)$ & 2286 & 1.065 & 0.889 & 0 & 1.099 & 1.792 \\
\hline Size & 2286 & 9.035 & 1.333 & 8.059 & 8.904 & 9.914 \\
\hline$M t B$ & 2286 & 3.737 & 4.700 & 1.460 & 2.454 & 4.132 \\
\hline$R O A$ & 2286 & 0.136 & 0.078 & 0.088 & 0.127 & 0.178 \\
\hline Return & 2286 & 0.162 & 0.318 & -0.008 & 0.149 & 0.316 \\
\hline Volume (in millions) & 2286 & 0.654 & 1.112 & 0.136 & 0.293 & 0.680 \\
\hline Volatility & 2286 & 0.078 & 0.042 & 0.049 & 0.066 & 0.095 \\
\hline Loss & 2286 & 0.091 & 0.287 & 0 & 0 & 0 \\
\hline
\end{tabular}


Panel E: Correlation matrix for the management earnings forecast sample

\begin{tabular}{|c|c|c|c|c|c|c|c|c|c|c|c|c|c|c|c|}
\hline$M F \_G N$ & 1 & & & & & & & & & & & & & & \\
\hline$M F \_$Bias & $-0.160^{*}$ & 1 & & & & & & & & & & & & & \\
\hline Price_Inwindow & $0.014 *$ & -0.011 & 1 & & & & & & & & & & & & \\
\hline Nonprice_Inwindow & 0.003 & 0.006 & $-0.027^{*}$ & 1 & & & & & & & & & & & \\
\hline Size & $0.054 *$ & $-0.041^{*}$ & $0.029^{*}$ & 0.007 & 1 & & & & & & & & & & \\
\hline$M t B$ & $0.038^{*}$ & $-0.032 *$ & $0.023^{*}$ & -0.012 & $0.134 *$ & 1 & & & & & & & & & \\
\hline AbRet & $0.096^{*}$ & $-0.039 *$ & 0.010 & -0.012 & 0.000 & -0.005 & 1 & & & & & & & & \\
\hline$R O A$ & $0.033^{*}$ & $-0.024 *$ & $-0.028^{*}$ & -0.009 & $0.122 *$ & $0.341^{*}$ & $-0.045^{*}$ & 1 & & & & & & & \\
\hline EarnVol & $-0.024 *$ & 0.006 & $0.032 *$ & -0.008 & $-0.212 *$ & $0.121 *$ & $0.027 *$ & 0.011 & 1 & & & & & & \\
\hline Loss & $-0.101 *$ & $0.043 *$ & $0.038^{*}$ & -0.003 & $-0.177 *$ & $0.053 *$ & $0.023 *$ & $-0.254 *$ & $0.274 *$ & 1 & & & & & \\
\hline Horizon & $0.022 *$ & $0.033 *$ & $-0.042 *$ & $-0.063^{*}$ & $0.071^{*}$ & 0.001 & $0.019^{*}$ & $-0.047 *$ & $-0.063^{*}$ & -0.008 & 1 & & & & \\
\hline Competition & $0.032 *$ & $-0.046^{*}$ & $0.044^{*}$ & -0.001 & 0.009 & $-0.013 *$ & 0.006 & $-0.193^{*}$ & -0.004 & $0.037^{*}$ & $0.055^{*}$ & 1 & & & \\
\hline InstitutionOwn & 0.010 & 0.004 & 0.011 & -0.002 & $-0.211 *$ & $0.031 *$ & $-0.020 *$ & $0.077 *$ & $0.097 *$ & -0.003 & $-0.058 *$ & $-0.126^{*}$ & 1 & & \\
\hline Ln_AnalystFollow & $0.013 *$ & $-0.024 *$ & 0.011 & 0.006 & $0.557^{*}$ & $0.111^{*}$ & $-0.015 *$ & $0.126^{*}$ & $-0.067^{*}$ & $-0.056^{*}$ & $0.014 *$ & $-0.053^{*}$ & -0.006 & 1 & \\
\hline \multicolumn{16}{|c|}{ Panel F: Correlation matrix for the CEO-year sample } \\
\hline \multicolumn{16}{|c|}{ Shrs_vest_scale 1} \\
\hline \multicolumn{3}{|c|}{ Adj_ $\bar{R} O A-$} & $-0.079 *$ & 1 & & & & & & & & & & & \\
\hline \multicolumn{3}{|c|}{$\log \left(1+I n w i n d o w \_M F \_G N \_c n t\right)$} & $0.197^{*}$ & $-0.083 *$ & 1 & & & & & & & & & & \\
\hline \multicolumn{3}{|c|}{ Shrs_target_scale } & $0.076^{*}$ & $0.125 *$ & -0.032 & 1 & & & & & & & & & \\
\hline \multicolumn{3}{|l|}{ Nonprice_Inwindow } & $-0.355^{*}$ & $0.171 *$ & $-0.206^{*}$ & 0.0 & $69 *$ & 1 & & & & & & & \\
\hline \multicolumn{3}{|l|}{ Size } & 0.008 & $0.264 *$ & -0.035 & 0.0 & $81 *$ & $0.192 *$ & 1 & & & & & & \\
\hline \multicolumn{3}{|l|}{$M t B$} & $-0.048^{*}$ & $0.689 *$ & $-0.055^{*}$ & 0.2 & $17 *$ & $0.175^{*}$ & $0.401 *$ & 1 & & & & & \\
\hline \multicolumn{3}{|l|}{ AbRet } & $0.075^{*}$ & $0.069 *$ & -0.010 & 0.0 & $60 *$ & $0.134 *$ & $0.123 *$ & $0.083 *$ & 1 & & & & \\
\hline \multicolumn{3}{|l|}{$R O A$} & $-0.169 *$ & $-0.071 *$ & $-0.090^{*}$ & -0.1 & $25^{*}$ & $0.441^{*}$ & $-0.056^{*}$ & $-0.077 *$ & $-0.080 *$ & 1 & & & \\
\hline \multicolumn{3}{|l|}{ EarnVol } & $0.170^{*}$ & $-0.146^{*}$ & $0.118^{*}$ & -0.0 & $94 *$ & $-0.446^{*}$ & $-0.096^{*}$ & $-0.121^{*}$ & $-0.103 *$ & $0.054^{*}$ & 1 & & \\
\hline \multicolumn{3}{|l|}{ Loss } & $0.106^{*}$ & $-0.328 *$ & $0.045^{*}$ & -0.1 & $22 *$ & $-0.271 *$ & $-0.044 *$ & $-0.328 *$ & $-0.125^{*}$ & $0.051 *$ & $0.394 *$ & & 1 \\
\hline
\end{tabular}




\section{Table 3 Favorable MEFs before the performance measurement period end}

This table presents the OLS estimation results of price-metric-induced good news but unbiased MEFs before the performance measurement period (PMP) end for the CEO's restricted stock grants (RSU). Column (1) and (3) present the univariate results with no fixed effects. Column (2) and (4) control factors identified in previous literature which affect the favorable of MEFs and year, quarter, and firm fixed effect. The dependent variable in column (1) and (2) is $M F \_G N$, which is measured as the management earnings forecast less the most recent prevailing consensus analyst forecast before the management forecast scaled by the stock price and multiplied by 100 . Column (3) and (4) use the MF_Bias, which is measured as management earnings forecast less the actual earnings scaled by the stock price and multiplied by 100 . We identify all RSUs' PMP end dates for which the number of vested grants will be determined for each CEO. We then construct two main explanatory variables: Price_Inwindow (Nonprice Inwindow) is an indicator variable that equals one if the management earnings forecast is issued within the 180-day window before the end of PMP for a grant that uses (does not use) stock price as a performance metric, zero otherwise. Definitions of the other variables are provided in Appendix A. $t$ statistics are presented in parentheses. The sample period ranges from 2006 through 2017. Standard errors are corrected for heteroscedasticity and are clustered at the firm level. *, **, and *** indicate significance levels at $10 \%, 5 \%$, and $1 \%$, respectively.

\begin{tabular}{|c|c|c|c|c|}
\hline \multirow[b]{2}{*}{ Independent variables } & \multicolumn{2}{|c|}{$M F \_G N$} & \multicolumn{2}{|c|}{ MF_Bias } \\
\hline & (1) & (2) & (3) & (4) \\
\hline \multirow[t]{2}{*}{ Price_Inwindow } & $0.104 * * *$ & $0.112 * * *$ & -0.067 & -0.040 \\
\hline & (3.36) & $(2.62)$ & $(-1.39)$ & $(-0.78)$ \\
\hline \multirow[t]{2}{*}{ Nonprice_Inwindow } & 0.025 & 0.008 & 0.032 & 0.059 \\
\hline & $(0.57)$ & $(0.22)$ & $(\mathbf{0 . 8 0})$ & (1.49) \\
\hline \multirow[t]{2}{*}{ Size } & & $0.159 * * *$ & & $0.092 * *$ \\
\hline & & $(3.12)$ & & $(2.47)$ \\
\hline \multirow[t]{2}{*}{$M t B$} & & $0.008^{* * *}$ & & $-0.013 * * *$ \\
\hline & & $(2.89)$ & & $(-3.59)$ \\
\hline \multirow[t]{2}{*}{ AbRet } & & $0.712 * * *$ & & $-0.330 * * *$ \\
\hline & & $(6.43)$ & & $(-5.40)$ \\
\hline \multirow[t]{2}{*}{$R O A$} & & -0.240 & & $1.225 * * *$ \\
\hline & & $(-0.92)$ & & $(3.47)$ \\
\hline \multirow[t]{2}{*}{ EarnVol } & & 1.347 & & -1.803 \\
\hline & & $(1.17)$ & & $(-1.65)$ \\
\hline \multirow[t]{2}{*}{ Loss } & & $-0.359 * * *$ & & 0.017 \\
\hline & & $(-4.13)$ & & $(0.41)$ \\
\hline \multirow[t]{2}{*}{ Horizon } & & -0.001 & & $0.244 * * *$ \\
\hline & & $(-0.03)$ & & $(4.87)$ \\
\hline \multirow[t]{2}{*}{ Competition } & & -0.109 & & 0.365 \\
\hline & & $(-0.28)$ & & $(0.75)$ \\
\hline \multirow[t]{2}{*}{ InstitutionOwn } & & 0.169 & & -0.112 \\
\hline & & $(1.05)$ & & $(-1.05)$ \\
\hline \multirow{2}{*}{ Ln_AnalystFollow } & & $-0.133 * * *$ & & 0.015 \\
\hline & & $(-2.97)$ & & $(0.34)$ \\
\hline \multirow[t]{2}{*}{ constant } & $-0.112 * * *$ & $-1.293 * * *$ & $-0.026^{*}$ & $-1.147 * * *$ \\
\hline & $(-8.06)$ & $(-3.32)$ & $(-1.85)$ & $(-3.66)$ \\
\hline Year FE, Quarter FE & No & Yes & No & Yes \\
\hline Firm FE & No & Yes & No & Yes \\
\hline Adj_R2 & 0.001 & 0.152 & 0.000 & 0.224 \\
\hline $\mathrm{N}$ & 26,828 & 26,828 & 26,828 & 26,828 \\
\hline
\end{tabular}




\section{Table 4 Cross-sectional variations in signaling demand}

This table reports the effects of signaling demand on the price-metric-induced positive MEF. The dependent variable is $M F \_G N$, which is measured as the management earnings forecast less the most recent prevailing consensus analyst forecast before the management forecast scaled by the stock price and multiplied by 100. LowRet_12 = 1 if the cumulated monthly stock return during the 12 months before the issuance of a management forecast is lower than the median, and 0 otherwise. High_InvAttention $=1$ if the aggregated existing institutional shareholders' exposures to all concurrent extreme returns of other stock holding is below the median. Price_Inwindow (Nonprice_Inwindow) is an indicator variable that equals one if the management earnings forecast is issued within the 180-day window before the end of PMP for a grant that uses (does not use) stock price as a performance metric, zero otherwise. The interaction terms stand for the moderating effects. Definitions of the other variables are provided in Appendix A. $t$-statistics are presented in parentheses. Standard errors are corrected for heteroscedasticity and are clustered at the firm level. *, **, and *** indicate significance levels at $10 \%, 5 \%$, and $1 \%$, respectively.

\begin{tabular}{|c|c|c|c|c|}
\hline & \multicolumn{2}{|c|}{$M F G N$} & \multicolumn{2}{|c|}{ MF Bias } \\
\hline & (1) & (2) & (3) & (4) \\
\hline Price_Inwindow*LowRet_12 & $\begin{array}{c}0.180 * * * \\
(2.62)\end{array}$ & & $\begin{array}{l}-0.132 \\
(-1.34)\end{array}$ & \\
\hline Nonprice_Inwindow $*$ LowRet_12 & $\begin{array}{l}0.016 \\
(0.22)\end{array}$ & & $\begin{array}{l}0.021 \\
(0.10)\end{array}$ & \\
\hline Price_Inwindow*High_InvAttention & & $\begin{array}{c}0.132 * * \\
(2.27)\end{array}$ & & $\begin{array}{l}0.026 \\
(0.26)\end{array}$ \\
\hline Nonprice_Inwindow* High_InvAttention & & $\begin{array}{l}-0.018 \\
(-0.24)\end{array}$ & & $\begin{array}{c}0.269 \\
(1.33)\end{array}$ \\
\hline Price_Inwindow & $\begin{array}{l}0.016 \\
(0.37)\end{array}$ & $\begin{array}{l}0.028 \\
(0.61)\end{array}$ & $\begin{array}{l}-0.009 \\
(-0.12)\end{array}$ & $\begin{array}{l}-0.087 \\
(-1.17)\end{array}$ \\
\hline Nonprice_Inwindow & $\begin{array}{l}0.004 \\
(0.18)\end{array}$ & $\begin{array}{l}0.015 \\
(0.35)\end{array}$ & $\begin{array}{c}0.153 * * \\
(2.00)\end{array}$ & $\begin{array}{l}-0.028 \\
(-0.43)\end{array}$ \\
\hline LowRet_12 & $\begin{array}{c}-0.084 * * * \\
(-5.78)\end{array}$ & & $\begin{array}{c}0.158 * * * \\
(5.38)\end{array}$ & \\
\hline High_InvAttention & & $\begin{array}{l}0.031 \\
(1.57)\end{array}$ & & $\begin{array}{l}-0.036 \\
(-1.04)\end{array}$ \\
\hline constant & $\begin{array}{c}-1.338^{* * * *} \\
(-3.26)\end{array}$ & $\begin{array}{c}-1.477 * * * \\
(-3.67)\end{array}$ & $\begin{array}{l}-0.377 \\
(-0.58)\end{array}$ & $\begin{array}{l}-0.075 \\
(-0.11)\end{array}$ \\
\hline Control variables & Yes & Yes & Yes & Yes \\
\hline Year FE, Quarter FE & Yes & Yes & Yes & Yes \\
\hline Firm FE & Yes & Yes & Yes & Yes \\
\hline Adj_R2 & 0.154 & 0.153 & 0.552 & 0.552 \\
\hline $\mathrm{N}$ & 26,828 & 26,776 & 26,828 & 26,776 \\
\hline
\end{tabular}




\section{Table 5 Market reactions after an MEF before the end of PMP}

This table reports the market reaction to the MEFs issued during the 180-day pre-window for the PMP end with or without a price metric. The two dependent variables are $C A R(-1,1)$, which is the cumulative abnormal return measured as the excess firm returns over the CRSP value-weighted returns during the 3day period around MEF and $C A R(2,30)$, which is the cumulative abnormal return during the month starting 2 days after issuance of MEF. $M F \_G N$ is measured as the management earnings forecast less the most recent prevailing consensus analyst forecast before the management forecast scaled by the stock price and multiplied by 100. Price_Inwindow (Nonprice_Inwindow) is an indicator variable that equals one if the management earnings forecast falls within the 180 -day window before the PMP end for a grant that uses (does not use) stock price as a performance metric, zero otherwise. The interaction terms stand for the different effect of Price_Inwindow or Nonprice_Inwindow on investors' response on MF_GN. Definitions of the other variables are provided in Appendix A. $t$-statistics are presented in parentheses. Standard errors are corrected for heteroscedasticity and are clustered at the firm level. *, **, and *** indicate significance levels at $10 \%, 5 \%$, and $1 \%$, respectively.

\begin{tabular}{|c|c|c|c|c|}
\hline & $\operatorname{CAR}(-1,1)$ & $\operatorname{CAR}(-1,1)$ & $\operatorname{CAR}(2,30)$ & CAR $(2,30)$ \\
\hline & (1) & (2) & (3) & (4) \\
\hline \multirow[t]{2}{*}{ Price_Inwindow*MF_GN } & $0.027 * * *$ & $0.030 * * *$ & -0.004 & -0.006 \\
\hline & $(3.96)$ & $(3.54)$ & $(-0.40)$ & $(-0.60)$ \\
\hline \multirow{2}{*}{ Nonprice_Inwindow*MF_GN } & 0.006 & 0.007 & -0.003 & 0.002 \\
\hline & $(1.08)$ & $(1.35)$ & $(-0.34)$ & $(0.31)$ \\
\hline \multirow[t]{2}{*}{$M F_{-} G N_{t}$} & $0.010 * * *$ & $0.011 * * *$ & -0.002 & -0.002 \\
\hline & $(3.64)$ & $(3.86)$ & $(-1.33)$ & $(-1.34)$ \\
\hline \multirow[t]{2}{*}{ Price_Inwindow } & 0.004 & 0.004 & 0.005 & -0.000 \\
\hline & $(1.38)$ & $(1.26)$ & $(1.28)$ & $(-0.04)$ \\
\hline \multirow{2}{*}{ Nonprice_Inwindow } & -0.002 & 0.002 & -0.000 & -0.000 \\
\hline & $(-0.64)$ & $(0.73)$ & $(-0.02)$ & $(-0.04)$ \\
\hline \multirow[t]{2}{*}{ Size } & & $-0.022 * * *$ & & $-0.038 * * *$ \\
\hline & & $(-10.71)$ & & $(-14.57)$ \\
\hline \multirow[t]{2}{*}{$M t B$} & & -0.000 & & $-0.001 * * *$ \\
\hline & & $(-0.41)$ & & $(-3.44)$ \\
\hline \multirow{2}{*}{ AbRet } & & -0.006 & & $0.060 * * *$ \\
\hline & & $(-1.55)$ & & $(7.63)$ \\
\hline \multirow{2}{*}{$R O A$} & & -0.013 & & -0.035 \\
\hline & & $(-0.77)$ & & $(-1.24)$ \\
\hline \multirow{2}{*}{ EarnVol } & & 0.054 & & -0.046 \\
\hline & & $(0.83)$ & & $(-0.44)$ \\
\hline \multirow[t]{2}{*}{ Loss } & & $-0.009 * * *$ & & 0.006 \\
\hline & & $(-3.08)$ & & $(1.58)$ \\
\hline \multirow{2}{*}{ Horizon } & & $0.006 * * *$ & & -0.001 \\
\hline & & $(4.85)$ & & $(-0.57)$ \\
\hline \multirow[t]{2}{*}{ Competition } & & 0.057 & & $-0.117^{* * *}$ \\
\hline & & $(1.31)$ & & $(-2.64)$ \\
\hline \multirow[t]{2}{*}{ InstitutionOwn } & & 0.002 & & -0.007 \\
\hline & & $(0.39)$ & & $(-1.03)$ \\
\hline \multirow[t]{2}{*}{ Ln_AnalystFollow } & & -0.003 & & $0.007 * * *$ \\
\hline & & $(-1.62)$ & & $(2.88)$ \\
\hline \multirow[t]{2}{*}{ constant } & $0.003 * * *$ & $0.205 * * *$ & $-0.001 *$ & $0.317 * * *$ \\
\hline & $(6.13)$ & $(11.74)$ & $(-1.87)$ & $(13.79)$ \\
\hline Year FE, Quarter FE & No & Yes & No & Yes \\
\hline Firm FE & No & Yes & No & Yes \\
\hline Adj_R2 & 0.032 & 0.069 & 0.001 & 0.081 \\
\hline $\mathrm{N}$ & 26,828 & 26,828 & 26,828 & 26,828 \\
\hline
\end{tabular}




\section{Table 6 Ex-post effects on CEO's vested share and accounting performance}

This table presents the effect of number of favorable MEFs that have been issued on vested shares of restricted stock (RSU) awarded to the CEO and accounting performance in the future. The dependent variable in column (1) is Shrs vest_scale, which is the number of shares vested for each CEO during each fiscal year scaled by the number of common shares outstanding. The dependent variable in column (2) is Adj_ROA, which is the industry adjusted return on asset in the awards vesting year. The main independent variable, Log $(1+$ Inwindow_MF_GN_cnt $)$, is the natural logarithm of one plus the total number of MEFs that are higher than the analyst forecasts that fall into the 180-day pre-event window before the PMP end date. Because each fiscal year could contain multiple PMP ends, the number is then averaged by each firm-fiscal year. We match the two datasets to make sure the fiscal year of the evaluation date is the same with the fiscal year in the stock vesting dataset. Shrs_target_scale is measured as the total number of shares expected to be earned if performance targets are met for all performance-based vesting grants for each CEO for that fiscal year scaled by the number of common shares outstanding. Definitions of the other variables are provided in Appendix A. $t$-statistics are presented in parentheses. Standard errors are corrected for heteroscedasticity and are clustered at the firm level. *,**, and *** indicate significance levels at $10 \%, 5 \%$, and $1 \%$, respectively.

\begin{tabular}{|c|c|c|}
\hline & Shrs_vest_scale & Adj_ROA \\
\hline & (1) & (2) \\
\hline \multirow[t]{2}{*}{ Log $\left(1+I n w i n d o w \_M F_{-} G N_{-} c n t\right)$} & $0.164 * * *$ & $0.003 * *$ \\
\hline & $(4.20)$ & $(2.17)$ \\
\hline \multirow[t]{2}{*}{ Shrs_target_scale } & 0.030 & \\
\hline & $(1.56)$ & \\
\hline \multirow[t]{2}{*}{ Size } & -0.060 & $0.012 * * *$ \\
\hline & $(-0.75)$ & $(3.27)$ \\
\hline \multirow[t]{2}{*}{$M t B$} & 0.007 & $0.001 * * *$ \\
\hline & $(1.25)$ & $(2.73)$ \\
\hline \multirow[t]{2}{*}{$R O A$} & -0.111 & \\
\hline & $(-0.16)$ & \\
\hline \multirow[t]{2}{*}{ Lag_ROA } & & $0.295 * * *$ \\
\hline & & $(6.46)$ \\
\hline \multirow[t]{2}{*}{ Return } & $0.164 *$ & -0.001 \\
\hline & $(1.89)$ & $(-0.37)$ \\
\hline \multirow[t]{2}{*}{ Volume } & 0.022 & 0.002 \\
\hline & $(0.51)$ & $(0.84)$ \\
\hline \multirow[t]{2}{*}{ Volatility } & 0.514 & -0.024 \\
\hline & $(0.51)$ & $(-0.68)$ \\
\hline \multirow[t]{2}{*}{ Loss } & $-0.265 * *$ & $-0.015 * * *$ \\
\hline & $(-2.10)$ & $(-2.86)$ \\
\hline \multirow[t]{2}{*}{ constant } & 0.749 & $-0.145 * * *$ \\
\hline & $(1.06)$ & $(-4.52)$ \\
\hline Firm FE & Yes & Yes \\
\hline Year FE & Yes & Yes \\
\hline Adj_R2 & 0.040 & 0.192 \\
\hline $\mathrm{N}$ & 2,286 & 2,286 \\
\hline
\end{tabular}




\section{Table 7 A placebo test for favorable MEFs before the PMP end with CEO turnover}

This table presents the OLS estimation results showing that for firms experiencing CEO turnover, the MEFs by incoming CEOs are not affected by the PMP end of the former CEO's restricted stock grants (RSU). The dependent variable is $M F \_G N$, which is measured as the management earnings forecast less the most recent prevailing consensus analyst forecast before the management forecast scaled by the stock price and multiplied by 100 . We identify all RSUs' PMP end dates for which the number of grants vested will be determined for each former CEO after the CEO turnover. We then construct two main explanatory variables: Price_Inwindow(Nonprice_Inwindow) is an indicator variable that equals one if the management earnings forecast falls within the 180-day window before the PMP end for a grant that uses (does not use) stock price as a performance metric, and zero otherwise. Definitions of the other variables are provided in Appendix A. $t$-statistics are presented in parentheses. The sample period ranges from 2006 through 2017. Standard errors are corrected for heteroscedasticity and are clustered at the firm level. *, **, and $* * *$ indicate significance levels at $10 \%, 5 \%$, and $1 \%$, respectively.

\begin{tabular}{|c|c|c|}
\hline & \multicolumn{2}{|c|}{$M F G N$} \\
\hline & (1) & (2) \\
\hline \multirow[t]{2}{*}{ Price_Inwindow } & 0.051 & 0.099 \\
\hline & $(0.49)$ & $(0.98)$ \\
\hline \multirow[t]{2}{*}{ Nonprice_Inwindow } & -0.009 & -0.050 \\
\hline & $(-0.17)$ & $(-0.99)$ \\
\hline \multirow{2}{*}{ Size } & & $0.179 * *$ \\
\hline & & $(2.19)$ \\
\hline \multirow[t]{2}{*}{$M t B$} & & $0.008^{*}$ \\
\hline & & $(1.72)$ \\
\hline \multirow[t]{2}{*}{ AbRet } & & $0.717 * * *$ \\
\hline & & $(4.45)$ \\
\hline \multirow[t]{2}{*}{$R O A$} & & -0.331 \\
\hline & & $(-0.99)$ \\
\hline \multirow{2}{*}{ EarnVol } & & 1.531 \\
\hline & & $(1.23)$ \\
\hline \multirow[t]{2}{*}{ Loss } & & $-0.322 * * *$ \\
\hline & & $(-3.13)$ \\
\hline \multirow[t]{2}{*}{ Horizon } & & -0.019 \\
\hline & & $(-0.59)$ \\
\hline \multirow[t]{2}{*}{ Competition } & & 0.572 \\
\hline & & $(1.11)$ \\
\hline \multirow[t]{2}{*}{ InstitutionOwn } & & 0.295 \\
\hline & & $(1.22)$ \\
\hline \multirow[t]{2}{*}{ Ln_AnalystFollow } & & -0.085 \\
\hline & & $(-1.23)$ \\
\hline \multirow[t]{2}{*}{ constant } & $-0.109 * * *$ & $-1.680 * * *$ \\
\hline & $(-5.29)$ & $(-2.94)$ \\
\hline Year FE, Quarter FE & No & Yes \\
\hline Firm FE & No & Yes \\
\hline Adj_R2 & 0.000 & 0.162 \\
\hline $\mathrm{N}$ & 15,033 & 15,033 \\
\hline
\end{tabular}




\section{Table 8 Comparing the magnitude of MEF bias with other confounding corporate events}

This table presents the results after controlling for the presence of other corporate events that have been identified as being linked to the strategic release of management earnings forecasts. We consider eleven types of corporate events: an annual meeting, a board meeting, a follow-on equity issuance, a private placement issuance, a fixed income offering, CEO turnover, a stock buyback announcement, the closing of a stock buyback, grant date, vesting date, and insider buy. The dummies for corporate events equal 1 if the MEF falls within the 30-day pre-event window around each corporate event. The dependent variable is $M F \_G N$, which is measured as the management earnings forecast less the most recent prevailing consensus analyst forecast before the management forecast scaled by the stock price and multiplied by 100. We identify all RSUs' performance measurement period end dates for which the number of grants vested will be determined for each CEO. We then construct two main explanatory variables: Price_Inwindow (Nonprice_Inwindow) is an indicator variable that equals one if the management earnings forecast falls within the 180-day window before the performance measurement period end for a grant that uses (does not use) stock price as a performance metric, zero otherwise. Definitions of the other variables are provided in Appendix A. $t$-statistics are presented in parentheses. The sample period ranges from 2006 through 2017. Standard errors are corrected for heteroscedasticity and are clustered at the firm level. *, **, and *** indicate significance levels at $10 \%, 5 \%$, and $1 \%$, respectively.

\begin{tabular}{|c|c|c|}
\hline & \multicolumn{2}{|c|}{$M F G N$} \\
\hline & (1) & (2) \\
\hline \multirow[t]{2}{*}{ Price_Inwindow } & $0.095 * * *$ & $0.102 * *$ \\
\hline & (3.09) & $(2.42)$ \\
\hline \multirow[t]{2}{*}{ Nonprice_Inwindow } & 0.020 & 0.000 \\
\hline & (0.39) & $(0.01)$ \\
\hline \multirow[t]{2}{*}{ Before_InsiderBuy } & $-0.295^{* * *}$ & $-0.176^{*}$ \\
\hline & $(-2.85)$ & $(-1.75)$ \\
\hline \multirow{2}{*}{ Before_FollowOnEquity } & $0.059^{*}$ & $0.073^{*}$ \\
\hline & $(1.65)$ & $(1.88)$ \\
\hline \multirow[t]{2}{*}{ After_BuybackClosing } & $0.063^{* *}$ & 0.032 \\
\hline & $(2.35)$ & $(1.24)$ \\
\hline \multirow[t]{2}{*}{ Before_PrivatePlacement } & 0.061 & -0.003 \\
\hline & $(1.00)$ & $(-0.05)$ \\
\hline \multirow[t]{2}{*}{ Before_FixedIncomeOffering } & -0.025 & -0.031 \\
\hline & $(-0.48)$ & $(-0.72)$ \\
\hline \multirow{2}{*}{ Before_AnnualMeeting } & -0.043 & -0.021 \\
\hline & $(-1.61)$ & $(-0.79)$ \\
\hline \multirow[t]{2}{*}{ Before_BoardMeeting } & -0.254 & -0.161 \\
\hline & $(-1.37)$ & $(-1.13)$ \\
\hline \multirow{2}{*}{ Before_CEOTurnover } & $-0.148 *$ & -0.136 \\
\hline & $(-1.71)$ & $(-1.59)$ \\
\hline \multirow[t]{2}{*}{ Before_BuybackAnnounce } & -0.015 & -0.024 \\
\hline & $(-0.49)$ & $(-0.81)$ \\
\hline \multirow[t]{2}{*}{ Before_GrantRSU } & -0.030 & -0.025 \\
\hline & $(-0.98)$ & $(-0.91)$ \\
\hline \multirow[t]{2}{*}{ Before_VestRSU } & 0.003 & -0.031 \\
\hline & $(0.09)$ & $(-1.06)$ \\
\hline \multirow{2}{*}{ constant } & $0.095 * * *$ & $0.102 * *$ \\
\hline & $(3.09)$ & $(2.42)$ \\
\hline Control variables & No & Yes \\
\hline Year FE, Quarter FE & No & Yes \\
\hline Firm FE & No & Yes \\
\hline Adj R2 & 0.002 & 0.151 \\
\hline $\mathrm{N}$ & 25,856 & 25,856 \\
\hline
\end{tabular}




\section{Table 9 Robustness tests with additional controls and alternative specifications}

This table presents robustness results. Panel A column (1) and (2) present results after controlling additional firm characteristics that may affect MEF issuance and with industry fixed effects rather than firm fixed effects. Panel A column (3) uses dependent variable $G N$, which equals one if $M F G N>0$, and zero otherwise. Panel B presents the results using a 90-day event window to construct the timing indicators. Price Inwindow [-90,0] (Nonprice Inwindow [-90,0]) is an indicator variable that equals one if the management earnings forecast falls within the 90-day window before the PMP end for a grant that uses (does not use) stock price as a performance metric, zero otherwise. Definitions of the other variables are provided in Appendix A. $t$-statistics are presented in parentheses. The sample period ranges from 2006 through 2017. Standard errors are corrected for heteroscedasticity and are clustered at the firm level. *,**, and $* * *$ indicate significance levels at $10 \%, 5 \%$, and $1 \%$, respectively.

Panel A: additional controls and propensity test

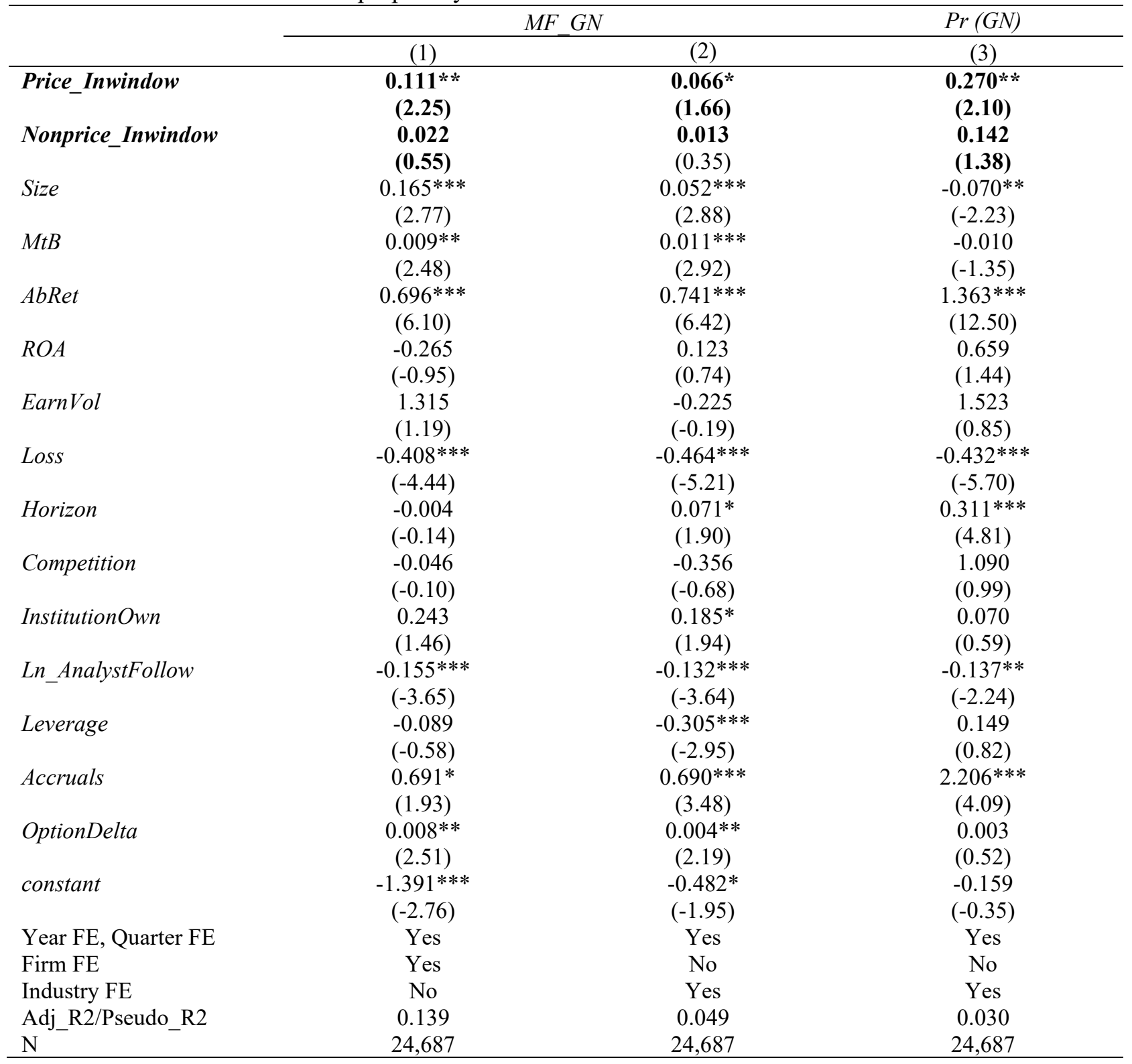


Panel B: Using a narrowed (90-day) window to define Price_Inwindow [-90,0]

\begin{tabular}{lcc}
\hline & & $M F \_G N$ \\
\cline { 2 - 3 } & $(1)$ & $(2)$ \\
\hline Price_Inwindow[-90,0] & $\mathbf{0 . 0 9 1 * * *}$ & $\mathbf{0 . 1 0 2} * *$ \\
Nonprice_Inwindow[-90,0] & $\mathbf{( 2 . 6 2 )}$ & $\mathbf{( 2 . 1 5 )}$ \\
& $\mathbf{- 0 . 0 2 0}$ & $\mathbf{0 . 0 0 5}$ \\
constant & $\mathbf{( - 0 . 2 6 )}$ & $\mathbf{( 0 . 0 6 )}$ \\
& $-0.110^{* * *}$ & $-1.296^{* * *}$ \\
All control variables & $(-8.10)$ & $(-3.43)$ \\
Year FE, Quarter FE & Yes & Yes \\
Firm FE & No & Yes \\
Adj_R2 & No & Yes \\
N & 0.001 & 0.152 \\
& 24,687 & 24,687 \\
\hline
\end{tabular}

